Review

\title{
Cetacean Morbillivirus: Current Knowledge and Future Directions
}

Marie-Françoise Van Bressem ${ }^{1, *}$, Pádraig J. Duignan ${ }^{2}$, Ashley Banyard ${ }^{3}$ Michelle Barbieri $^{4}$, Kathleen M Colegrove ${ }^{5}$, Sylvain De Guise ${ }^{6}$, Giovanni Di Guardo ${ }^{7}$, Andrew Dobson ${ }^{8}$, Mariano Domingo ${ }^{9}$, Deborah Fauquier ${ }^{10}$, Antonio Fernandez ${ }^{11}$, Tracey Goldstein ${ }^{12}$, Bryan Grenfell ${ }^{8,13}$, Kátia R. Groch ${ }^{14,15}$, Frances Gulland ${ }^{4,16}$, Brenda A Jensen ${ }^{17}$, Paul D Jepson ${ }^{18}$, Ailsa Hall ${ }^{19}$, Thijs Kuiken ${ }^{20}$, Sandro Mazzariol ${ }^{21}$, Sinead E Morris ${ }^{8}$, Ole Nielsen ${ }^{22}$, Juan A Raga ${ }^{23}$, Teresa K Rowles ${ }^{10}$, Jeremy Saliki ${ }^{24}$, Eva Sierra ${ }^{11}$, Nahiid Stephens ${ }^{25}$, Brett Stone ${ }^{26}$, Ikuko Tomo ${ }^{27}$, Jianning Wang ${ }^{28}$, Thomas Waltzek ${ }^{29}$ and James FX Wellehan ${ }^{30}$

1 Cetacean Conservation Medicine Group (CMED), Peruvian Centre for Cetacean Research (CEPEC), Pucusana, Lima 20, Peru

2 Department of Ecosystem and Public Health, University of Calgary, Calgary, AL T2N 4Z6, Canada; E-Mail: ppjduign@ucalgary.ca

3 Wildlife Zoonoses and Vector Borne Disease Research Group, Animal and Plant Health Agency (APHA), Weybridge, Surrey KT15 3NB, UK; E-Mail: ashley.banyard@apha.gsi.gov.uk

4 The Marine Mammal Centre, Sausalito, CA 94965, USA; E-Mails: michelle.barbieri@noaa.gov (M.B.); gullandf@tmmc.org (F.G.)

5 Zoological Pathology Program, College of Veterinary Medicine, University of Illinois at Maywood, IL 60153, USA; E-Mail: katie.colegrove@gmail.com

6 Department of Pathobiology and Veterinary Science, and Connecticut Sea Grant College Program, University of Connecticut, Storrs, CT 06269, USA; E-Mail: sylvain.deguise@uconn.edu

7 Faculty of Veterinary Medicine, University of Teramo, 64100 Teramo, Italy; E-Mail: gdiguardo@unite.it

8 Department of Ecology and Evolutionary Biology, Princeton University, Princeton, NJ 08544, USA; E-Mails: dobson@princeton.edu (A.D.); grenfell@princeton.edu (B.G.); semorris@princeton.edu (S.E.M.)

9 Centre de Recerca en Sanitat Animal (CReSA), Autonomous University of Barcelona, Bellaterra, Barcelona 08193, Spain; E-Mail: Mariano.Domingo@cresa.uab.cat

10 National Marine Fisheries Service, Marine Mammal Health and Stranding Response Program, Silver Spring, MD 20910, USA; E-Mails: deborah.fauquier@noaa.gov (D.F.); teri.rowles@noaa.gov (T.K.R.) 
11 Department of Veterinary Pathology, Institute of Animal Health, Veterinary School, Universidad de Las Palmas de Gran Canaria, Las Palmas 35413, Spain;

E-Mails: afernandez@dmor.ulpgc.es (A.F.); esierra@becarios.ulpgc.es (E.S.)

12 One Health Institute School of Veterinary Medicine University of California, Davis, CA 95616, USA; E-Mail: tgoldstein@ucdavis.edu

13 Fogarty International Center, National Institutes of Health, Bethesda, MD 20892, USA

14 Department of Pathology, School of Veterinary Medicine and Animal Sciences, University of São Paulo, São Paulo 05508-207, Brazil; E-Mail: katia.groch@gmail.com

15Instituto Baleia Jubarte (Humpback Whale Institute), Caravelas, Bahia 45900-000, Brazil

16 Marine Mammal Commission, 4340 East-West Highway, Bethesda, MD 20814, USA

17 Department of Natural Sciences, Hawai i Pacific University, Kaneohe, HI 96744, USA; E-Mail: bjensen@hpu.edu

18 Institute of Zoology, Regent's Park, London NW1 4RY, UK; E-Mail: paul.jepson@ioz.ac.uk

19 Sea Mammal Research Unit, Scottish Oceans Institute, University of St. Andrews, St. Andrews KY16 8LB, UK; E-Mail: ajh7@st-andrews.ac.uk

${ }^{20}$ Department of Viroscience, Erasmus MC, Rotterdam 3015 CN, The Netherlands; E-Mail: t.kuiken@erasmusmc.nl

21 Department of Comparative Biomedicine and Food Science, University of Padua, Padua 35020, Italy; E-Mail: sandro.mazzariol@unipd.it

22 Department of Fisheries and Oceans Canada, Central and Arctic Region, 501 University Crescent, Winnipeg, MB R3T 2N6, Canada; E-Mail: ole.nielsen@dfo-mpo.gc.ca

23 Marine Zoology Unit, Cavanilles Institute of Biodiversity and Evolutionary Biology, University of Valencia, Valencia 22085, Spain; E-Mail: raga@uv.es

24 Athens Veterinary Diagnostic Laboratory, College of Veterinary Medicine, University of Georgia, Athens, GA GA 30602 ,USA; E-Mail: jsaliki@uga.edu

25 School of Veterinary and Life Sciences, Murdoch University, Perth 6150, Western Australia, Australia; E-Mail: n.stephens@murdoch.edu.au

${ }^{26}$ QML Vetnostics, Metroplex on Gateway, Murarrie, Queensland 4172, Australia; E-Mail: brett.stone@qml.com.au

27 South Australian Museum, North Terrace, Adelaide 5000, South Australia, Australia; E-Mail: ikuko.tomo@samuseum.sa.gov.au

28 Commonwealth Scientific and Industrial Research Organisation (CSIRO), East Geelong, Victoria 3220, Australia; E-Mail: Jianning.Wang@csiro.au

29 Department of Infectious Diseases and Pathology, College of Veterinary Medicine, University of Florida, Gainesville, FL 32611, USA; E-Mail: tomwaltzek@gmail.com

30 Department of Small Animal Clinical Sciences, College of Veterinary Medicine, University of Florida, Gainesville, FL 32611, USA; E-Mail: wellehanj@ufl.edu

* Author to whom correspondence should be addressed; E-Mail: mfb.cmed@gmail.com; Tel.: +49-30-53051397. 
Received: 7 November 2014; in revised form: 2 December 2014 / Accepted: 16 December 2014 / Published: 22 December 2014

\begin{abstract}
We review the molecular and epidemiological characteristics of cetacean morbillivirus (CeMV) and the diagnosis and pathogenesis of associated disease, with six different strains detected in cetaceans worldwide. CeMV has caused epidemics with high mortality in odontocetes in Europe, the USA and Australia. It represents a distinct species within the Morbillivirus genus. Although most CeMV strains are phylogenetically closely related, recent data indicate that morbilliviruses recovered from Indo-Pacific bottlenose dolphins (Tursiops aduncus), from Western Australia, and a Guiana dolphin (Sotalia guianensis), from Brazil, are divergent. The signaling lymphocyte activation molecule (SLAM) cell receptor for CeMV has been characterized in cetaceans. It shares higher amino acid identity with the ruminant SLAM than with the receptors of carnivores or humans, reflecting the evolutionary history of these mammalian taxa. In Delphinidae, three amino acid substitutions may result in a higher affinity for the virus. Infection is diagnosed by histology, immunohistochemistry, virus isolation, RT-PCR, and serology. Classical CeMV-associated lesions include bronchointerstitial pneumonia, encephalitis, syncytia, and lymphoid depletion associated with immunosuppression. Cetaceans that survive the acute disease may develop fatal secondary infections and chronic encephalitis. Endemically infected, gregarious odontocetes probably serve as reservoirs and vectors. Transmission likely occurs through the inhalation of aerosolized virus but mother to fetus transmission was also reported.
\end{abstract}

Keywords: cetacean morbillivirus; epidemics; mass stranding; SLAM; phylogeny; pathogenesis; diagnosis; endemic infections

\title{
1. Introduction
}

Cetacean morbillivirus (CeMV) is a recently described member of the genus Morbillivirus, subfamily Paramyxovirinae, family Paramyxoviridae, Order Mononegavirales, that includes three well characterized strains: the porpoise morbillivirus (PMV), first isolated from harbor porpoises (Phocoena phocoena) from Northern Ireland [1], the dolphin morbillivirus (DMV), first isolated from Mediterranean striped dolphins (Stenella coeruleoalba) [2,3], and the pilot whale morbillivirus (PWMV), recovered from a long-finned pilot whale (Globicephala melas) stranded in New Jersey, USA [4] (Figure 1). Recently, three new strains were detected by reverse transcription polymerase chain reaction (RT-PCR), one in a Longman's beaked whale (Indopacetus pacificus) from Hawaii, one in a Guiana dolphin (Sotalia guianensis) from Brazil and one in two Indo-Pacific bottlenose dolphins (Tursiops aduncus) from Western Australia [5-7] (Figure 1). Over the past three decades, cetacean morbilliviruses have caused several outbreaks of lethal disease in odontocetes (toothed whales) and mysticetes (baleen whales) around the world. 

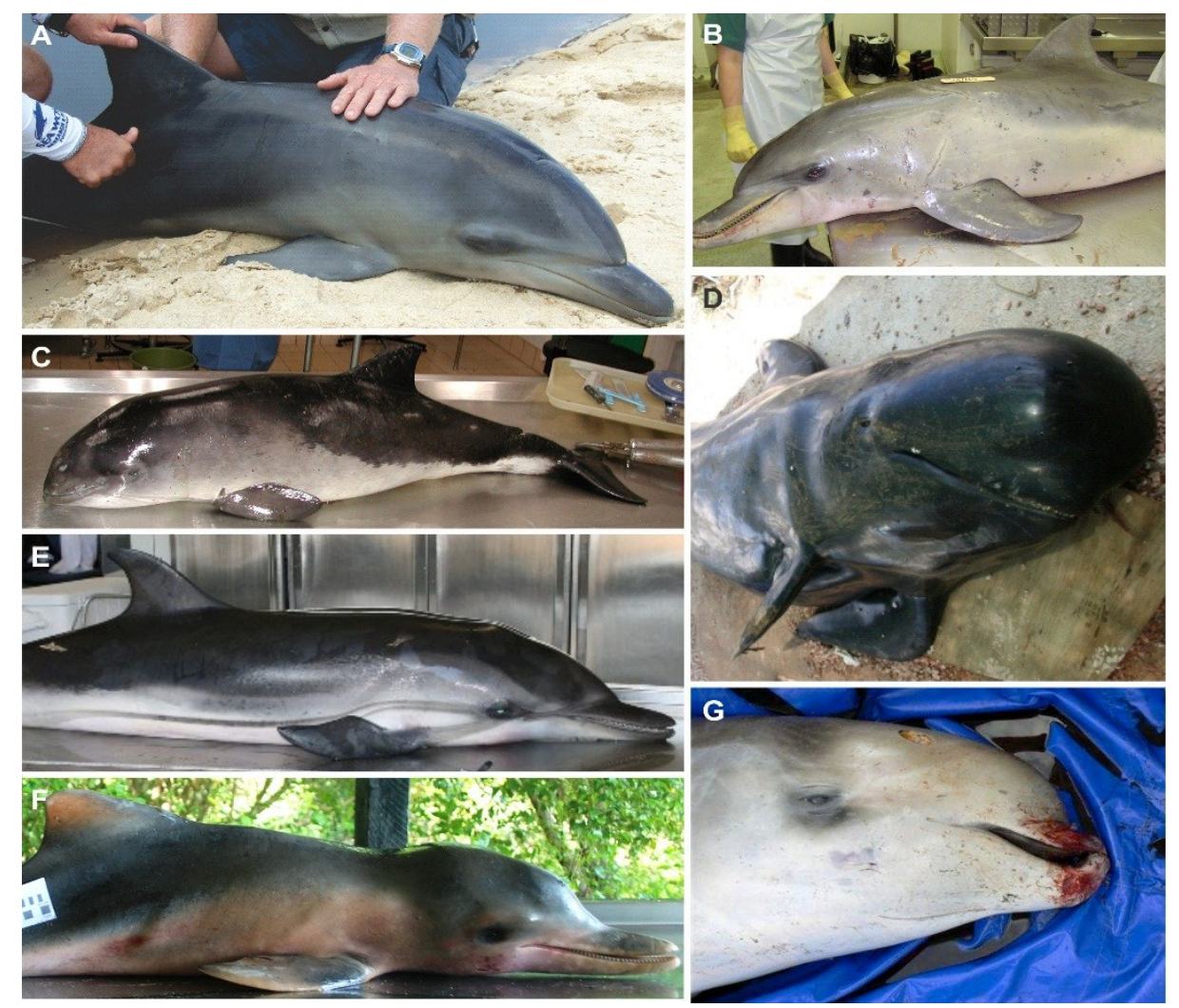

Figure 1. Cetacean species in which the six CeMV strains were isolated or detected by RT-PCR. (A) Common bottlenose dolphin (Tursiops truncatus), Fraser Island, Australia, 2010 (C) E. Pearce); (B) Indo-Pacific bottlenose dolphin (Tursiops aduncus), Swan River, Perth, Australia, 2009 (C N. Stephens); (C) Harbour porpoise (Phocoena phocoena), Kent, UK, 2005 (C R. Deaville); (D) Long-finned pilot whale (Globicephala melas), Alicante, Spain, 2007 (C) A.J. Raga); (E) Striped dolphin (Stenella coeruleoalba), Valencia, Spain, 2007 (C) A.J. Raga); (F) Emaciated calf Guiana dolphin (Sotalia guianensis), Guriri, Espirito Santo, Brazil 2010 (C K. Groch); (G) Longman's beaked whale (Indopacetus pacificus), Hawaii, US, March 2010 (C K. West, Hawaii Pacific University, NOAA Permit number 932-1905).

Other important pathogens in the genus Morbillivirus are measles virus in humans and other primates, rinderpest and peste des petits ruminants viruses in artiodactyls, canine and phocine distemper viruses in carnivores and tentatively, a paramyxovirus from domestic cats currently named feline morbillivirus [8-11]. Morbilliviruses are lymphotropic and initially replicate in lymphoid tissue before infecting epithelial cells [12,13]. All are very contagious and cause serious disease with immunosuppression in their hosts. Cetacean and pinniped morbilliviruses were first recognized in 1988 following a series of epidemics in Northwestern Europe. A symposium in Hannover, Germany, in 1994 reviewed these events and the cross-disciplinary research conducted in several countries and laboratories worldwide at that time $[14,15]$. Twenty years later in August 2014, a Research and Policy for Infectious Disease Dynamics (RAPIDD) workshop was convened at Princeton University, USA, to discuss the disease outbreaks and findings since then, and identify future directions for research. As a product of that workshop, here we review the antigenic, molecular, pathological and epidemiological characteristics of CeMV worldwide and discuss topics for further research. 


\section{Antigenic and Molecular Characteristics of CeMV}

Morbilliviruses are unsegmented, linear negative-sense, single-stranded RNA viruses. The DMV genome is 15,702 nucleotides long and consists of six transcription units that encode six structural proteins, the nucleocapsid protein $(\mathrm{N})$, phosphoprotein $(\mathrm{P})$, matrix protein $(\mathrm{M})$, fusion glycoprotein $(\mathrm{F})$, haemagglutinin glycoprotein $(\mathrm{H})$ and the RNA-dependent RNA polymerase $(\mathrm{L})$, as well as two virulence factor proteins (C and V) [9,16-20]. PMV and DMV are antigenically closely related, showing a similar reaction pattern with monoclonal antibodies $(\mathrm{MoAb})$ raised against $\mathrm{CDV}$, phocine distemper virus (PDV), peste des petits ruminants (PPRV) and rinderpest (RPV) proteins [21,22]. Serological surveys performed in cetaceans from the US and Europe showed that mean antibody titers were consistently similar to both DMV and PMV [22-26]. PMV and DMV are antigenically more closely related to the ruminant morbilliviruses and measles virus (MV) than to the distemper viruses [15]. Sequencing of the P, N, F and M genes further demonstrated and confirmed that PMV and DMV are closely related and that they form a separate group within the Morbillivirus genus, closer to the ruminant viruses and MV than to the CDV/PDV group (Figure 2) [9,16-18,20,27]. There is a higher (18.3\%) divergence between PMV and DMV at the level of the C-terminal end of the $\mathrm{N}$ gene, a hypervariable domain, than between different MV isolates [17,18,28]. However, in other $\mathrm{F}$ and $\mathrm{N}$ gene regions there are fewer differences between these strains than between strains of CDV [18,20]. Thus, the present consensus is that PMV and DMV represent two strains of CeMV [16,18,20,29]. Analyses of partial P and N gene sequences of a morbillivirus (PWMV) recovered in a long-finned pilot whale (Globicephala melas) from New Jersey, USA, suggested that it belongs to the CeMV lineage but is distinct from PMV and DMV, and that it should be considered as a third strain of CeMV [4]. Sequence analysis of the N, P, F and H genes of another isolate from a short-finned pilot whale (Globicephala macrorhynchus) stranded on the Canary Islands in the Central Eastern (CE) Atlantic showed 97\% homology with the G. melas PWMV and further confirmed a distinct strain circulating among pilot whale species [30]. However, pilot whales are also susceptible to infection by DMV [27,31]. G. melas and S. coeruleoalba that died along the coasts of Spain during the 2006-2008 Mediterranean epidemic were both infected by DMV strains that showed $100 \%$ identity across the $\mathrm{H}$ gene [27] and $99.9 \%$ identity over $9050 \mathrm{bp}$ [31]. Similarly, P gene fragments of isolates recovered from T. truncatus and G. melas stranded along the Mediterranean coast of France in 2007-2008 were 100\% identical to the Spanish G. melas isolate [32]. Altogether these results indicated that the same DMV strain circulated in the Mediterranean Sea and infected different cetacean species during the 2006-2008 outbreak. Furthermore, sequences of DMV strains recovered from Mediterranean cetaceans during the 2006-2008 epidemic and from S. coeruleoalba washed ashore in the Canary Islands in 2002-2011 were highly conserved across the short genome region characterized (Figure 2) [33]. However, there was only $99.4 \%$ and $99.3 \%$ identity between the isolates form the 1990-92 epidemic and those from the 2006-2008 events based on the nearly complete genomes (9050 bp) [19,31]. Thus, these data suggest that the 1990-1992 strain was not maintained in the Mediterranean Sea between the epidemics, and that the strain circulating in the CE Atlantic Ocean was introduced in the Mediterranean Sea in 2006. The DMV Mediterranean strains are less closely related to the isolates recovered from L. albirostris stranded in Germany and the Netherlands in 2007-2011 (Figure 2), suggesting that this North Sea strain did not play a role in the epidemics $[31,34]$. However, further research is needed to better understand the circulation of CeMV in European waters. 


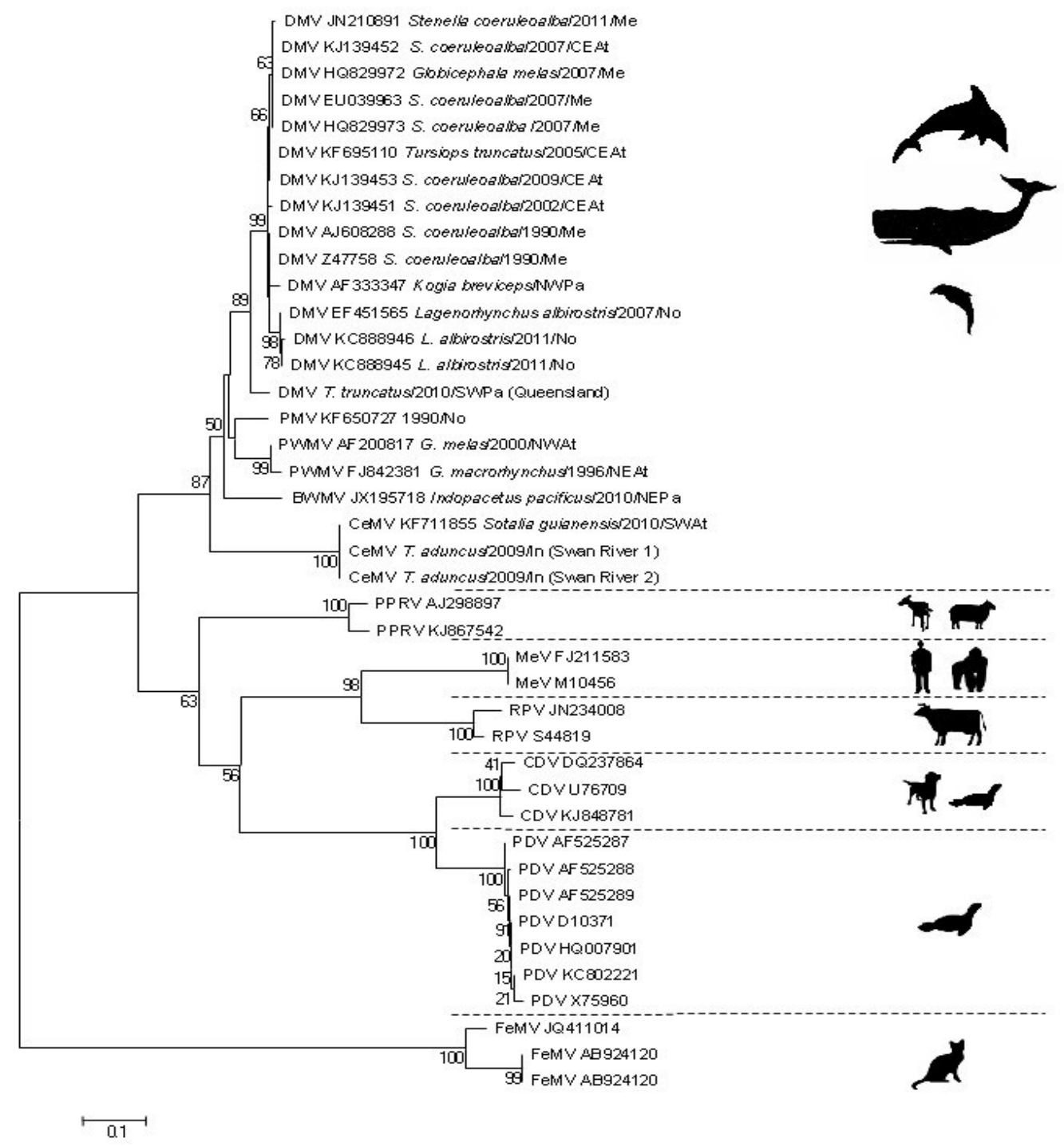

Figure 2. Phylogenetic analysis of a fragment of the morbillivirus $P$ gene. Sequences were trimmed to include all sequence data available. Each sequence is denoted by its accession number (where available) and strain/isolate details (cetacean species, and year and geographic area of stranding). The evolutionary history of the isolates assessed was inferred using the neighbour-joining method with branch lengths in the same units as those of the evolutionary distances used to infer the phylogenetic tree. The evolutionary distances were computed using the Kimura 2-parameter method and are in the units of the number of base substitutions per site detailed with bootstrap values of $>50$ being shown against key nodes. The phylogeny includes 41 nucleotide sequences with a total of 253 positions in the final dataset. Evolutionary analyses were conducted in MEGA5 [35]. Abbreviations are: BWMV, beaked whale morbillivirus, DMV, dolphin morbillivirus; CeMV, cetacean morbillivirus; PMV, porpoise morbillivirus; PWMV, pilot whale morbillivirus; PPRV, peste-des-petits-ruminants virus; RPV; rinderpest virus; $\mathrm{CDV}$, canine distemper virus; PDV, phocine distemper virus; $\mathrm{MeV}$, measles virus; NEAt, Northeastern Atlantic Ocean; CEAt, Central Eastern Atlantic Ocean; NWAt, Northwest Atlantic Ocean; SWAt, Southwest Atlantic Ocean; Me, Mediterranean Sea; No, North Sea; NEPa, Northeastern Pacific Ocean; NWPa, Northwest Pacific Ocean; SWPa, Southwest Pacific Ocean; In, Indian Ocean. 
Very little is known about the three new CeMV related strains recently detected in odontocetes from Hawaii, Brazil, and Australia [5-7]. However, recent sequencing data of the $\mathrm{P}$ gene of the isolates recovered from two T. aduncus from the west coast of Australia (Indian Ocean) and from a S. guianensis from Brazil suggest that they differ significantly from the DMV, PMV and PWMV strains [6,7] and may represent another CeMV lineage (Figure 2). The beaked whale morbillivirus (BWMV) clusters with the 'old' CeMV lineage and should be considered as a new strain of this lineage (Figure 2). Sequences from a fragment of the $\mathrm{P}$ gene revealed that it has $86 \%$ similarity to DMV and $84 \%$ similarity to PWMV [5]. We propose to use the terminology CeMV-1 for the 'old' lineage that includes DMV, PMV, PWMV and BWMV and CeMV-2 for the 'new' lineage that includes the T. aduncus and S. guianensis morbilliviruses until the taxonomy of these viruses is further explored.

The close genetic relationship between cetacean and ruminant morbilliviruses has led to the suggestion that they may have a common ancestor [7,16]. Closely related to the hippopotamus (Hippopotamus amphibius), cetaceans belong to the clade Cetartiodactyla [36,37]. As several species of this clade are susceptible to RPV and PPRV [38,39], it is possible that a host jump occurred between a cetacean and another member of the Cetartiodactyla, and that ecological isolation led to distinct virus species. The presence of similar host proteins and cell receptors in cetaceans and artiodactyls may favour cross-species transmission $[9,13,40]$. However, further studies are needed to confirm this hypothesis.

\section{Mechanisms of Cellular Entry and Receptors}

The $\mathrm{H}$ glycoprotein is responsible for virus attachment to the host cell membrane and for cellular entry. The F glycoprotein causes fusion with the host cell membrane and, together with the M protein, invokes cell-to-cell fusion [20,41]. $\mathrm{H}$ and $\mathrm{F}$ interact with cellular receptors that allow virus entry and determine host susceptibility, tissue tropism and viral pathogenesis [12,42]. The signaling lymphocyte activation molecule (SLAM or CD150) and the poliovirus like receptor 4 (PVLR4 or nectin 4) have both been recently identified as the major receptors for wild-type morbilliviruses in immune and polarized epithelial cells, respectively $[9,13,42-45]$. Besides, CD147, a transmembrane glycoprotein that belongs to the immunoglobulin family and is present on a variety of cells including neuronal and endothelial cells, and the membrane bound form of heparin binding epithelial growth factor have been suggested to function as entry receptors for MeV and PDV, respectively [42,46]. Most morbilliviruses, including MV, CDV, PDV, PPRV, and RPV use the SLAM of their respective host species as a receptor $[42,43,47,48]$.

Phylogenetic trees based on the structure of the SLAM and $\mathrm{H}$ proteins indicated that they co-evolved [9]. The SLAM receptors have immunoglobulin-like variable (V) and constant-2 (C2) domains in their extracellular regions with the $\mathrm{V}$ domain providing an interface for the morbillivirus $\mathrm{H}$ glycoprotein [49]. Substitution in the amino acid residues of this interface may lead to a loss of, a reduction in, or an increase in, viral infectivity [13]. The morbillivirus $\mathrm{H}$ glycoprotein displays a strong affinity for this domain in its respective host [13]. However, a recent study showed that only one amino acid exchange in $\mathrm{H}$ was required for functional adaptation of CDV to the human SLAM cell receptor in vitro [50]. The SLAM receptor has been characterized in seven species of mysticetes and in 19 species of odontocetes [9,13]. Three-dimensional homology models showed that there are 32 amino acid residues on the interface of cetacean SLAM that may contribute to morbillivirus binding [13]. The similarity of the 32 residues was higher between the cetacean and cow SLAMs (26 amino acid 
residues) than between the Pacific white-sided dolphin (Lagenorhynchus obliquidens) and the spotted seal (Phoca largha) SLAM (21 amino acid residues) [9,13], as would be expected based on the host relationships. Among the nine cetacean families examined, variations were found between six amino acid residues, with charge alterations for four of them [13]. Interestingly, three residue substitutions (G68, H90 and H130) that introduced charge alteration and possible change in viral affinity were observed in the SLAM of the Delphinidae, while these residues were mostly conserved in the receptor of the other cetacean families [13]. As morbillivirus mass mortalities have mostly been detected in the Delphinidae, it is possible that their SLAMs have a higher affinity for CeMV resulting in increased viral infectivity and dissemination [13]. Among the Delphinidae, only T. truncatus, T. aduncus and, $S$. coeruleoalba had variation at position 130 [13] and during CeMV outbreaks mass die-offs were overwhelmingly dominated by these species [7,51,52]. The only other odontocete that presented this H130Q variation was $P$. phocoena, a species that was affected by morbillivirus infection in 1988-1990 [53,54]. Further studies are needed to confirm if the SLAM of dolphins, porpoises and whales is indeed the immune cell receptor for CeMV and should investigate whether alternate potential receptors, such as nectin 4 and CD147, are present on the cells of these mammals.

\section{Diagnosis}

Though virus isolation remains the gold standard for definitive diagnosis, it is challenging when dealing with stranded cetacean carcasses. RT-PCR followed by sequencing has proven very helpful for obtaining rapid confirmation of CeMV infection, to differentiate between PMV and DMV and to identify new strains $[4-7,16,20,55]$. Histology and immunohistochemistry have provided further confirmation of the disease and insights into its pathogenesis and have permitted differentiation between systemic disease and localized chronic infection of the central nervous system (CNS) [56-60]. Serological studies have also been useful for studying CeMV epidemiology, to assess the immune status of populations before and after an outbreak and to predict the occurrence of new epidemics [21,23,24,26,61-65].

\subsection{Histology and Immunohistochemistry}

Classical histological techniques have been used to investigate CeMV disease and pathogenesis since the first $P$. phocoena and Mediterranean $S$. coeruleoalba were suspected of dying of morbillivirus infection [2,53]. Immunohistochemistry (IHC) has greatly enhanced the sensitivity and specificity of histopathological diagnosis by enabling the detection of morbillivirus antigen in cases where tissue preservation is poor or where classical lesions have been obscured by opportunistic pathogens. IHC studies have been conducted by using a commercially available MoAb for CDV N protein [5-7,33,66-69], a MoAb for PDV hemagglutinin [2,53,57], or a rabbit polyclonal antiserum to rinderpest virus [70]. Together with RT-PCR, these techniques recently permitted the identification of morbillivirus outbreaks in T. truncatus and T. aduncus from South Australia in 2013 [51], and in T. truncatus from the NW Atlantic, ongoing since 2013 [71]. At the time of writing specific MoAb for DMV or PMV proteins are not commercially available although they would be useful for accurate diagnosis and research in the future. Histology and IHC techniques should always be used to confirm the molecular diagnosis of systemic morbillivirus infection during an outbreak of mortality. 


\subsection{Virus Isolation}

The isolation of DMV and PMV has been achieved using homogenates of lung tissue from $S$. coeruleoalba and P. phocoena inoculated onto monolayers of African green monkey kidney (Vero) cells following standard methodologies [1,3,22]. Primary canine kidney epithelial cell cultures, bovine foetal lung cells and T. truncatus peripheral blood mononuclear cells have also proved useful for isolation of CeMV directly or after co-cultivation with Vero cells [1,17,21]. Primary culture of kidney cells derived from diseased P. phocoena permitted direct virus isolation [22]. Repeated passages of the inoculated cell cultures and, consequently, several weeks are typically needed before virus growth can be detected [17,22]. Recently, Vero cells expressing the canine SLAM (Vero.DogSLAMtag cells) were shown to reduce the time necessary for PDV isolation from weeks to days [72]. These cells were also successfully used to grow stocks of PMV and DMV initially passaged on Vero cells and to isolate DMV from the brain of a G. melas stranded in Valencia during the 2006-2008 epidemic [27,55,67]. More recently, they proved useful to isolate CeMV from fresh tissues as part of the investigation into the T. truncatus morbillivirus outbreak along the eastern Atlantic coast of USA in 2013 [71]. Virus isolation has the added benefit of providing antigen necessary to carry out serological testing, as described in the serology section below. It may also provide genomic material for more complete phylogenetic analysis.

\subsection{Serology}

Virus neutralization (VN) tests, plaque reduction (PR) assays and indirect enzyme-linked immunosorbent assays (iELISAs) are the main platforms used to detect antibodies against CeMV. The iELISA allows the detection of antibodies directed against the N, P, F and H CeMV proteins [73] whereas only antibodies to the surface glycoproteins ( $\mathrm{H}$ and $\mathrm{F}$ ) are detected by the VN and PR assays [16]. Morbilliviruses are antigenically closely related and may cross-neutralize one another. However, serum raised against one morbillivirus will neutralize the homologous virus at a higher titer than it will heterologous morbilliviruses $[63,74]$. Thus, when working with cetaceans it is very important to use CeMV strains in the serological tests to avoid false negatives.

Indirect ELISAs were developed to analyze hemolyzed serum samples that could be cytotoxic and, as such, could prevent the detection of morbillivirus antibodies at low dilutions in virus neutralization tests [61,62]. These assays used whole DMV [61-63] or the recombinant N protein of RPV [75] to detect morbillivirus antibodies. Cetacean antibodies were detected using horseradish-peroxidase-conjugated protein A, a cell wall constituent of Staphylococcus aureus that binds non-specifically the immunoglobulins of several species of vertebrates including odontocetes [21,76]. Recently, purified DMV-N protein expressed from a baculovirus (Autographa californica nuclear polyhedrosis virus) vector was used as the coating antigen in the iELISA and permitted the detection of morbillivirus antibodies in the sera of odontocetes [77]. The iELISA appears to be more sensitive than the classical $\mathrm{VN}$ test and may be useful as a serological tool for the mass screening of morbillivirus antibodies in cetaceans. A competitive ELISA using MoAbs to CDV and PDV was developed for testing sera from various species of marine mammals. Its main advantage over iELISAs is that a single anti-mouse immunoglobulin conjugate can be used on serum from any animal species [74]. However, sensitivity was lower for detection of cetacean compared to carnivore morbilliviruses [74]. 
The VN test is highly sensitive and very specific and is considered the most reliable assay for the detection of CeMV antibodies [74]. Antibody titers are expressed as the reciprocal of the highest dilution of sera that completely neutralizes cytopathic effects. Titers of 1:16 or higher are considered to be indicative of exposure to CeMV, although higher thresholds can be used to reduce the likelihood of false positives. A more conservative interpretation is recommended when either new host species or new geographic areas are under investigation. A PR assay was developed to allow detection of antibodies in hemolyzed sera [78,79]. In this test, titers are expressed as the reciprocal of the highest dilution that gave $80 \%$ reduction in the number of plaques compared to the negative control [79]. Although Vero cells are most commonly utilized in these tests, use of Vero. DogSLAMtag cells, which allows for improved virus replication and permits reduction of incubation time from nine days to four days ([72]; Saliki, unpublished observations) may be a more robust and cost-effective alternative.

\subsection{Reverse Transcription Polymerase Chain Reaction}

A "universal" morbillivirus primer set, based on highly conserved regions of the morbillivirus $\mathrm{P}$ gene identified by Barrett et al. [16] has been successfully used to detect CeMV by RT-PCR during outbreaks worldwide [6,7,68,70,75]. Using a similar approach, Krafft et al. [80] designed a protocol that allows amplification of degraded RNA in formalin-fixed paraffin embedded samples and in unfixed autolyzed tissues. This technique was useful to confirm CeMV infection in fixed tissues from D. delphis stranded along the coast of California in 1995-1997 and in cases of chronic encephalitis in Mediterranean $S$. coeruleoalaba $[56,75]$. Since then, other primers including sets of "universal" morbillivirus primers based on the conserved $\mathrm{N}$ terminus of the morbillivirus $\mathrm{N}$ gene, were also successfully used to detect CeMV [67]. A real-time RT-PCR (rtRT-PCR) that targets the hypervariable C terminal domain of the N gene was developed by Grant et al. [55] for a rapid and differential detection of dolphin and porpoise morbilliviruses. This test is rapid, very sensitive and specific for either DMV or PMV and does not cross-react with CDV, PDV, RPV, PPRV and MV [55]. A rtRT-PCR assay that targeted the glyceraldehyde 3-phosphate dehydrogenase (GAPDH) gene, as a house-keeping gene, was developed to determine whether total RNA extracted from stranded cetacean tissues is amplifiable [55]. This test allowed for the detection of GAPDH gene sequences from 14 marine mammal species and is essential for interpreting negative results with the morbillivirus RT-PCRs. Another rtRT-PCR was later designed to amplify a highly conserved region within the F gene and to differentiate between DMV, PMV, and PWMV $[81,82]$. More recently, a pan-marine mammal morbillivirus semi-nested RT-PCR using a degenerate set of primers targeting conserved sequences of the $\mathrm{P}$ gene was described [33] for the detection of both pinniped and cetacean morbilliviruses. Such an assay is useful for detecting morbilliviruses in multiple marine mammal species. The L primers, described by Woo et al. [11], may also be helpful for detecting CeMV in odontocetes and mysticetes. Clearly, with all the advances in molecular biology, diagnosing CeMV infection has become much faster, easier and more reliable. RT-PCR assays should be used together with the other techniques to distinguish among acute infection, prolonged persistence of morbillivirus RNA following CeMV acute disease, and chronic infection. When CeMV infection is detected in a novel host species, samples should be sequenced for species confirmation and identification and also sent to morbillivirus reference centers for genetic confirmation of the species involved. 


\section{Pathology and Pathogenesis of CeMV Infection}

Most morbilliviruses are lymphotropic and epitheliotropic [12]. After initial replication in the lymphoid tissues, the virus is disseminated by infected lymphocytes through the lymphatic system and spreads to epithelial cells $[12,83-86]$. Histology and immunohistochemistry data indicate that CeMV-associated pathology resembles that commonly seen in other morbillivirus infections in animal and human hosts [54].

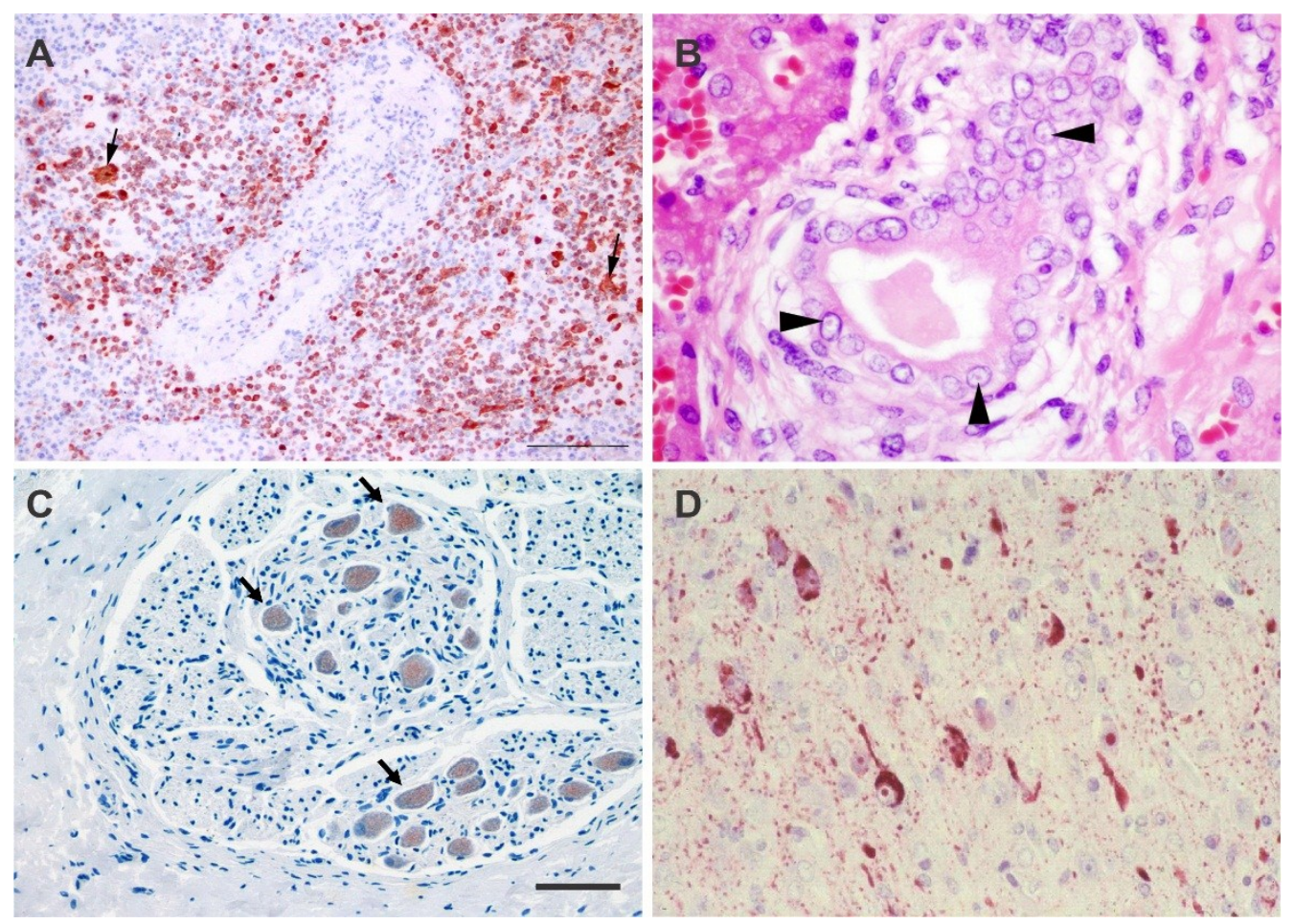

Figure 3. (a) Bottlenose dolphin (Tursiops truncatus), pulmonary lymph node, DMV infection, Canary Islands, Spain, 2005 (C) IUSA, ULPGC). Positive intranuclear and intracytoplasmic immunoperoxidase staining of morbilliviral antigen in mononuclear and multinucleated giant syncytial cells (arrows). Avidin-biotin-peroxidase with Harri's hematoxylin counterstain $\times 250(20 \times$ objective $)$; (b) Common bottlenose dolphin (Tursiops truncatus), liver and bile ductule, DMV infection, United States, 2014 (C K. Colegrove). Small eosinophilic intranuclear inclusions within biliary epithelial cells (arrows). $\times 750$ $(60 \times$ objective); (c) Guiana dolphin (Sotalia guianensis), glandular stomach, CeMV infection, São Mateus, Brazil, 2010. Granular immunohistochemical staining of morbilliviral antigen in neuronal cytoplasm in the myenteric plexus. Avidin-biotin complex immunoperoxidase technique, Mayer's haematoxylin counterstain. Bar $=50 \mu \mathrm{m}$. (C) Katia Groch); (d) Striped dolphin (Stenella coeruleoalba), brain, DMV infection, Latium, Italy, 1993 (C G. Di Guardo). Strong immunohistochemical labeling of morbilliviral antigen in cortical neurons, intranuclear viral inclusion bodies and in the surrounding neuropil. Avidin-biotin peroxidase technique with Mayer's haematoxylin counterstain $\times 500$ $(40 \times$ objective $)$. 


\subsection{Acute, Systemic Disease}

Acutely fatal CeMV infection is generally associated with severe multifocal to diffuse interstitial broncho-pneumonia characterized by necrosis of type I pneumocytes and bronchiolar epithelial cells, interstitial oedema, type II pneumocyte hyperplasia, and formation of large syncytia in the alveolar and bronchiolar lumina. Intracytoplasmic and intranuclear inclusion bodies can be noted and are sometimes numerous in respiratory epithelia, bronchiolar gland epithelia and the syncytial cells. Generalized lymphoid depletion with germinal center necrosis is usually present and syncytial cells (Warthin-Finkeldey type) are often prominent in lymphoid tissues (Figure 3A). There may be evidence of viral replication (inclusion bodies) in epithelia and neural cells of other body systems (Figure 3B,C). Multifocal non-suppurative encephalitis may also be present (Figure 3D). Therefore, there may be strong IHC staining in the lungs, lymphoid organs (Figure 3A) and other tissues that is variable in extent between individual cases $[7,54,57,59,60,68,87]$.

\subsection{Sub-Acute Systemic Disease}

Animals that survive the acute stage of infection may succumb to opportunistic infections (Toxoplama gondii, herpesviruses, bacteria such as Photobacterium damselae, and fungi) as a consequence of the profound immunosuppression. This typical pattern has been commonly seen in odontocetes that died during outbreaks of CeMV in Europe, South America, the USA and Australia [6,7,32,57-60,68,88-91]. While some of the lesions typical of acute infection may no longer be present or be largely obscured by the inflammatory response to the opportunistic pathogens, non-suppurative demyelinating meningoencephalitis (Figure 3D), often focally distributed, is a feature of sub-acute infection. Colonization of the brain by opportunistic mycotic pathogens (e.g., Aspergillus spp.) is also common [7,59]. IHC and RT-PCR are useful for confirmation of the diagnosis of morbilliviral infection in these cases.

\subsection{Chronic Systemic Infection}

Animals may survive the acute and sub-acute manifestations of infection but succumb sometime later to the secondary infections acquired as a result of viral immunosuppression, or from complications of CNS infection. Typically these animals are in poor body condition at the time of death and the proximate cause of death may be multifactorial. Invariably there are no or few lesions directly attributable to CeMV but viral antigen may be detectable by IHC in some lymph nodes and lungs [57] and viral RNA may be amplified by RT-PCR [57,92].

This chronic form of infection was a feature of the 1987-1988 T. truncatus epizootic off the US Atlantic coast, where confirmation of morbillivirus infection was only possible using IHC (53\% of 79 cases) [57] and RT-PCR (86\% of 29 IHC negative cases) [92]). More recently, chronic CeMV infection was detected in two T. aduncus from Western Australia [7]. It was characterized by pronounced lymphoid depletion and severe secondary infections and the almost complete absence of typical morbillivirus lesions in the lungs and brain. Morbillivirus antigen was detected in lymphoid tissues, as well as in the hepatic sinusoidal endothelial cells and Kupffer cells, biliary epithelium, and tunica media myocytes of blood vessels within the liver and mesenteric lymph nodes but not in the lungs or brain [7]. RT-PCR amplified morbilliviral RNA in the same tissues. These results suggested that the dolphins had 
survived the acute phase of the infection but died following profound immunosuppression and secondary infections [7]. If the pathogenesis of CeMV is similar to that of MV [93], cetaceans that survived acute and sub-acute infection could show prolonged RNA persistence in the blood and lymphoid organs and could be RT-PCR positive in the absence of typical morbillivirus lesions. The concurrent use of histology, IHC and molecular techniques is recommended to further explore the pathogenesis of chronic systemic infections.

\subsection{Chronic, Localized CeMV Encephalitis}

Cetaceans that have cleared and resolved DMV systemic infection may develop a CNS form that is characterized by the presence of lesions and virus only in the brain $[33,56,66,94]$. This CNS form was consistently observed in $S$. coeruleoalba after the two epidemics in the Mediterranean Sea [56,94]. By contrast with the sub-acute cerebral CeMV infection, cytoplasmic or nuclear eosinophilic inclusions were only occasionally detected and syncytial cells were not observed in the CNS form. Many neuronal processes showed immunostaining for CeMV, and some areas had massive accumulation of CeMV-antigen, while contiguous zones of the brain had almost no staining. This suggests that the presence of CeMV was more the result of cell-to-cell spreading of infection rather than of a multifocal infection indicative of blood-borne infection. The CNS form appears to share histological characteristics with subacute sclerosing panencephalitis (SSPE) and old dog encephalitis (ODE), chronic latent localized infections that affect humans and dogs, respectively, and are caused by defective forms of MV and CDV, respectively [95-97]. As in SSPE and ODE, the CNS lesions were localized predominantly in the cerebral cortex, subcortical white matter, and the thalamus, while the cerebellum was mostly spared. In the three conditions perivascular cuffing, diffuse gliosis, and glial nodules with neurophagia were the most prominent changes [94]. Focal malacia was not detected [94,96,98-100]. Demyelination was less prominent in dolphins with the exclusively CNS presentation and in dogs with ODE than is seen in the meningoencephalitis of CeMV or CDV, respectively [56,66,94,101,102]. As in the human and canine presentations, antigen and viral RNA could be detected in dolphin brains but the virus proved difficult to isolate [101]. The mechanism for this is unknown but delayed clearance of antigen and RNA from the CNS may be related to reduced immune surveillance in an immuno-privileged site [99,100]. RT-PCR studies on the brain of $S$. coeruleoalba chronically affected by CeMV suggest that the sequence of the $\mathrm{P}$ gene is different in these cases [56], but further research is needed. The role of CD147 and other cell receptors in the pathogenesis of this form of the disease should be further examined [103].

The prevalence of the DMV-CNS form in S. coeruleoalba seems to be higher in dolphins than prevalence of SSPE in humans. Indeed, in a hypothetical scenario where the whole central Mediterranean S. coeruleoalba population (15,778 individuals; $95 \% \mathrm{CI}=10,940$ to 22,756 [104]) was exposed to DMV during the 2006-2008 epidemic, the proportional morbidity rate of CNS-localized infection would be between 141 and 293 per 100,000 cases [56]. In a recent study in Germany, the risk of developing SSPE after acute measles infection in children below five years of age was estimated to range from 1:1700 to $1: 3300$ (30.3 to 58.8 per 100,000 cases) in 2003-2009 [105]. Further research should explore true age-weighted prevalence of this syndrome in dolphins. There are no comparable data for ODE though it is assumed to be a very rare complication of CDV infection. The significance of this related to epidemiology remains to be determined. However, the diversity of cetacean morbilliviruses 
seems greater than that seen within other morbillivirus species. This is unexpected for a virus that induces lifelong immunity and high cross-protection between congeneric viruses in long-lived hosts. It is possible that CNS persistence plays a role in the maintenance of strains in an ocean basin, although, as a dead end infection, it is unlikely to contribute to virus transmission to other cetaceans.

Although the CNS form has been mostly described in Mediterranean S. coeruleoalba, a similar presentation was described in a few other sporadic cases, namely a mature L. obliquidens stranded on the coast of Miyasaki, Japan, in March 1998 [106], in a juvenile white-beaked dolphin (Lagenorhynchus albirostris) that beached on the island of Ameland, the Netherlands, in June 2011 and died in a rehabilitation center six months later [34], in four S. coeruleoalba stranded along the coasts of the Canary Islands in 2002-2011 [33], and in several T. truncatus from North America (Colegrove, pers. observation). The CNS form was not detected in P. phocoena from the North Sea and Northeastern (NE) Atlantic, although the brains from relatively few animals were examined [107]. Current data would suggest that of the three known strains of CeMV, the DMV variant is the only one associated with the chronic CNS presentation. However, it is also the most prevalent variant detected in nature, and much more research would be required before conclusions could be drawn.

\subsection{Subclinical Infection}

The pathogenesis and clinical course of morbillivirus infections in cetaceans are poorly understood as there are no comparable laboratory studies to those on CDV in dogs and MV in primates [85,108]. Acute and subacute systemic presentations and chronic CNS infection causing death have been documented, as described in preceding sections. However, the existence and nature of subclinical infection remains speculative. Between 1995-1997, a series of DMV seropositive (> 1:50) D. delphis beached along the southern California coast [75]. One of the six dolphins survived and developed very high titers (1:720) against DMV while in rehabilitation. The other five were euthanized and, at necropsy, none had classical morbillivirus lesions. However, one had a mild lymphocytic meningoencephalitis and its brain was positive for morbillivirus RNA by RT-PCR, as described in Mediterranean S. coeruleoalba. Morbilliviral RNA was also detected in the spleen and heart of two other dolphins without histological lesions [75]. Whether this actually represents subclinical infection in D. delphis or an atypical viral strain/host presentation in the eastern Pacific is unknown.

Similarly, a low prevalence of serum antibodies in apparently healthy live-captured T. truncatus from the Indian River Lagoon, on Florida's Atlantic coast, without a prior increase in mortalities in the population was suggestive of virus circulation in the absence of an epidemic and thus, of subclinical infection [64]. However, this is a complex system with documented evidence of repeated CeMV epidemics over a period of at least 1982 to 2013 [25,57,72]. Thus, a better understanding of CeMV pathogenesis and immunity in dolphins is required before we can adequately interpret findings from field investigations.

\subsection{Immune Function and CeMV Infections}

Morbillivirus infections have long been known to result in host immune suppression [109-112]. Recent studies suggest similar effects in naturally infected, wild T. truncatus sampled as part of capture-release studies for health assessment. Bossart et al. [65] reported a significant decrease in 
mitogen-induced $\mathrm{T}$ cell proliferation along with an increase in lysozyme concentrations and a marginally significant increase in monocyte phagocytosis, along with a marginally significant decrease in the numbers of CD4+ $\mathrm{T}$ lymphocytes in $T$. truncatus that had antibody titers $\geq 1: 8$ against morbillivirus, suggestive of previous exposure to the virus, compared to animals with lower or no titers. They found no effects on neutrophil phagocytosis. While the timing of the morbillivirus infection (active infection, chronic infection, resolved past infection) cannot be determined from titers alone, it is clear that there is an association between modulation of immune functions and previous exposure to morbillivirus infection in T. truncatus, as observed in other species. Further studies are needed.

\subsection{CeMV Transmission}

\subsubsection{Horizontal Transmission}

Morbillivirus transmission is thought to occur mostly after the inhalation of aerosolized virus shed by infected individuals [113]. This horizontal transmission is likely to occur among cetaceans too and to be favored by a gregarious behavior and a high density of cetaceans [67,114]. Transmission by inhalation of expired blowhole droplets possibly occurs during breathing in a synchronized fashion when large numbers of tightly grouped cetaceans are travelling and feeding together or are engaged in social activities $[20,115,116]$.

\subsubsection{Evidence for Vertical Transmission}

Morbillivirus antigen was detected in the mammary gland of T. truncatus from the US Atlantic coast epidemic in 1987-1988 and of S. coeuruleoalba from the Mediterranean Sea outbreak in 1990 [59,87] and in the penile and preputial epithelium of a P. phocoena from the North Sea [107]. Furthermore, a testicular fibroma collected in a short-beaked common dolphin (Delphinus delphis ponticus) from the Black Sea was positive for morbillivirus RNA by RT-PCR [117]. The first evidence that vertical transmission may occur was the detection of morbilliviral RNA in the brain, lung, spleen, lymph node, and liver from the seven-month fetus of a DMV-infected G. melas stranded in the Balearic Islands in 2007 [88]. These data suggest that CeMV infected females may transmit the infection to their fetuses and neonates in utero and during lactation, respectively. In utero transmission has been reported for MV in humans. The effects on the fetus depend on the stage of pregnancy and include abortion, in utero death or premature birth [118]. When MV infects pregnant women in the peri-natal period, neonates are at risk of congenital measles and have a higher risk of developing early and fulminant SSPE because of the incomplete transfer of protective antibodies [96,119]. A similar situation may have happened in a S. coeruleoalba calf stranded in Italy in November 2009 with a CNS infection [120] and in a neonate sperm whale (Physeter macrocephalus) washed ashore in Oahu, Hawaii in May of 2011 [121].

\section{Outbreaks of Disease and Epidemiology}

Morbilliviruses are extremely infectious and are likely to infect most of the immunologically naive individuals in a population. Herd formation and migration increase the probability of transmission [37,113]. Morbilliviruses require large populations of susceptible individuals (e.g., 300,000 for measles virus in humans) to persist endemically, as there is no carrier state and infection confers lifelong immunity [113]. 
However, the persistence of morbilliviruses in relatively small (possibly multispecies) host metapopulations remains an important unsolved problem in disease ecology [122]. Newborn individuals typically have maternal immunity if their mothers had previously been infected. After some months, this immunity is lost and the young individuals are fully susceptible to infection $[123,124]$.

CeMV infection has been detected using various techniques in several species of odontocetes and mysticetes worldwide (Table 1). DMV is the strain most commonly observed in cetaceans from the Northern Hemisphere, followed by PMV and PWMV (Table 1). Serological studies strongly suggest that CeMV is endemic in gregarious odontocete species in the North Atlantic and, possibly in the Southwestern Atlantic and in the South Pacific [23-25,61,63]. Pilot whale (Globicephala spp.), dusky dolphin (Lagenorhynchus obscurus), Fraser's dolphin (Lagenodelphis hosei) and melon-headed whale (Peponocephala electra) populations had high prevalences of DMV-seropositives and may be reservoirs and vectors of the infection to susceptible species $[23-25,62,63,90]$. In the absence of, or decrease in, herd immunity, outbreaks of lethal disease may occur in susceptible species, as has repeatedly been observed in Europe, the Americas, and Australia since the late 1980s.

Table 1. CeMV infection in odontocetes and mysticetes worldwide. Abbreviations are: VI = virus isolation, IHC = immunohistochemistry, $\mathrm{S}=$ serology, RT-PCR = reverse-transcriptase polymerase chain reaction, $\mathrm{PMV}=$ porpoise morbillivirus, $\mathrm{CeMV}=$ cetacean morbillivirus, $\mathrm{DMV}=$ dolphin morbillivirus, $\mathrm{PWMV}=$ pilot whale morbillivirus and CeMV, $\mathrm{NL}=$ new lineage of CeMV.

\begin{tabular}{|c|c|c|c|c|c|c|}
\hline $\begin{array}{l}\text { Ocean } \\
\text { Provinces/Species }\end{array}$ & Years & Countries & $\begin{array}{l}\text { Epidemiolo- } \\
\text { gical Status }\end{array}$ & Diagnosis & Virus & $\begin{array}{c}\text { Literature } \\
\text { Cited }\end{array}$ \\
\hline \multicolumn{7}{|l|}{ Eastern Atlantic \& } \\
\hline North Sea & & & & & & \\
\hline Phocoena phocoena & 1988-1990 & $\begin{array}{l}\text { N. Ireland, UK, } \\
\text { Netherlands }\end{array}$ & $\begin{array}{l}\text { periodic } \\
\text { mortalities }\end{array}$ & $\begin{array}{l}\text { VI, IHC, S, } \\
\text { RT-PCR }\end{array}$ & PMV & $\begin{array}{l}{[1,22,53],} \\
{[54,61,63]}\end{array}$ \\
\hline Delphinus delphis & $1988-1990$ & UK, Netherlands & unknown & $\mathrm{S}$ & CeMV & {$[22,61,63]$} \\
\hline $\begin{array}{l}\text { Lagenorhynchus } \\
\text { albirostris }\end{array}$ & $\begin{array}{l}1988-1990 \\
2007,2011\end{array}$ & $\begin{array}{l}\text { Germany, } \\
\text { Netherlands }\end{array}$ & $\begin{array}{l}\text { periodic } \\
\text { mortalities }\end{array}$ & $\begin{array}{l}\text { S, IHC, } \\
\text { RT-PCR }\end{array}$ & DMV & $\begin{array}{c}{[22,34,61,} \\
125]\end{array}$ \\
\hline Balaenoptera physalus & 1983 & Iceland & unknown & $\mathrm{S}$ & CeMV & [17] \\
\hline B. physalus & 1997-1998 & Belgium, France & $\begin{array}{l}\text { periodic } \\
\text { mortalities }\end{array}$ & $\mathrm{IHC}$ & unknown & [126] \\
\hline Tursiops truncatus & 1999 & Kent, UK & unknown & $\mathrm{S}$ & CeMV & {$[63]$} \\
\hline $\begin{array}{l}\text { Globicephala } \\
\text { macrorhynchus }\end{array}$ & 1996 & Canary Islands & $\begin{array}{c}\text { periodic } \\
\text { mortalities }\end{array}$ & RT-PCR & PWM & {$[30]$} \\
\hline T. truncatus & 2005 & Canary Islands & $\begin{array}{l}\text { periodic } \\
\text { mortalities }\end{array}$ & IHC, RT-PCR & DMV & [69] \\
\hline S. coeruleoalba & 2002-2011 & Canary Islands & $\begin{array}{l}\text { periodic } \\
\text { mortalities }\end{array}$ & IHQ, RT-PCR & DMV & {$[33]$} \\
\hline D. delphis & 2007 & Canary Islands & $\begin{array}{c}\text { periodic } \\
\text { mortalities }\end{array}$ & IHQ, RT-PCR & DMV & [33] \\
\hline
\end{tabular}


Table 1. Cont.

\begin{tabular}{|c|c|c|c|c|c|c|}
\hline $\begin{array}{l}\text { Ocean } \\
\text { Provinces/Species }\end{array}$ & Years & Countries & $\begin{array}{l}\text { Epidemiolo- } \\
\text { gical Status }\end{array}$ & Diagnosis & Virus & $\begin{array}{c}\text { Literature } \\
\text { Cited }\end{array}$ \\
\hline \multicolumn{7}{|l|}{ Mediterranean Sea } \\
\hline S. coeruleoalba & 1990-1992 & $\begin{array}{c}\text { Spain, France, Italy, } \\
\text { Greece }\end{array}$ & epidemic & $\begin{array}{l}\text { VI, IHC, S, } \\
\text { RT-PCR }\end{array}$ & DMV & $\begin{array}{c}{[2,3,21,58,} \\
127]\end{array}$ \\
\hline S. coeruleoalba & 2006-2008 & Spain, France, Italy & epidemic & IHC, RT-PCR & DMV & {$[32,66,67]$} \\
\hline T. truncatus & $\begin{array}{l}1994 ; 2007- \\
2008,2011\end{array}$ & $\begin{array}{l}\text { Israel, Spain, France, } \\
\text { Italy }\end{array}$ & $\begin{array}{l}\text { periodic } \\
\text { mortalities }\end{array}$ & $\begin{array}{c}\text { IHC, } \\
\text { RT-PCR, S }\end{array}$ & DMV & $\begin{array}{c}{[32,63,66,} \\
128]\end{array}$ \\
\hline D. delphis & 1990 & Italy & unknown & $\mathrm{S}$ & CeMV & [21] \\
\hline Globicephala melas & 2006-2007 & Spain, France & epidemic & IHQ, RT-PCR & DMV & [88] \\
\hline Grampus griseus & 1997, 1999 & Valencia, Spain & unknown & $\mathrm{S}$ & CeMV & [63] \\
\hline $\begin{array}{l}\text { Balaenoptera } \\
\text { acutorostrata }\end{array}$ & 1993 & Tuscany, Italy & unknown & $\mathrm{S}$ & unknown & {$[58]$} \\
\hline B. physalus & 2011 & Tuscany, Italy & $\begin{array}{l}\text { periodic } \\
\text { mortalities }\end{array}$ & RT-PCR & DMV & [89] \\
\hline \multicolumn{7}{|l|}{ Northwestern Atlantic } \\
\hline T. truncatus & 1982 & Florida, USA & epidemic & $\mathrm{S}, \mathrm{IHC}$ & CeMV & {$[25,129]$} \\
\hline T. truncatus & $1987-1988$ & East coast USA & epidemic & $\begin{array}{c}\text { IHC, } \\
\text { RT-PCR }\end{array}$ & CeMV & {$[57,92]$} \\
\hline T. truncatus & 1993-1994 & $\begin{array}{c}\text { Gulf of Mexico, } \\
\text { USA }\end{array}$ & epidemic & IHC, RT-PCR & CeMV & {$[25,57,92]$} \\
\hline T. truncatus & $2003-2007$ & Florida, USA & unknown & $\mathrm{S}, \mathrm{IHC}$ & CeMV & {$[64,65]$} \\
\hline T. truncatus & 2013-2014 & East coast USA & epidemic & IHC, RT-PCR & DMV & {$[71,130]$} \\
\hline T. truncatus & 1992-1994 & East coast USA & endemic & $\mathrm{S}$ & CeMV & {$[25]$} \\
\hline G. melas & $1982-1993$ & Northeast coast USA & endemic & $\mathrm{S}$ & CeMV & [23] \\
\hline G. macrorhynchus & 1986-1994 & Florida, USA & endemic & S & CeMV & [23] \\
\hline G. melas & late nineties & New Jersey, USA & $\begin{array}{l}\text { periodic } \\
\text { mortalities }\end{array}$ & $\begin{array}{c}\text { IHC, } \\
\text { RT-PCR }\end{array}$ & PWM & {$[4]$} \\
\hline S. coeruleoalba & 1991-1993 & Northeast coast USA & unknown & S & CeMV & [24] \\
\hline Stenella frontalis & 1993 & Northeast coast USA & unknown & $\mathrm{S}$ & CeMV & [24] \\
\hline D. delphis & 1980-1994 & Northeast coast USA & $\begin{array}{l}\text { possibly } \\
\text { endemic }\end{array}$ & $\mathrm{S}$ & CeMV & [24] \\
\hline $\begin{array}{l}\text { Lagenorhynchus } \\
\text { acutus }\end{array}$ & 1985-1993 & Northeast coast USA & unknown & S & CeMV & [24] \\
\hline Kogia breviceps & 1983-1991 & Southeast coast USA & unknown & S & CeMV & [24] \\
\hline Feresa attenuata & 1983 & Southeast coast USA & unknown & $\mathrm{S}$ & CeMV & [24] \\
\hline Pseudorca crassidens & $1982-1988$ & Southeast coast USA & $\begin{array}{l}\text { possibly } \\
\text { endemic }\end{array}$ & $\mathrm{S}$ & CeMV & [24] \\
\hline Lagenodelphis hosei & 1994 & $\begin{array}{l}\text { Gulf of Mexico, } \\
\text { USA }\end{array}$ & $\begin{array}{l}\text { possibly } \\
\text { endemic }\end{array}$ & $\mathrm{S}$ & CeMV & [24] \\
\hline P. phocoena & 1993-1994 & East coast, Canada & unknown & $\mathrm{S}$ & CeMV & [24] \\
\hline \multicolumn{7}{|l|}{ Southwestern Atlantic } \\
\hline L. hosei & 1999 & $\begin{array}{l}\text { Puerto Madryn, } \\
\text { Argentina }\end{array}$ & unknown & $\mathrm{S}$ & CeMV & {$[63]$} \\
\hline L. hosei & 1999 & $\begin{array}{c}\text { Rio de Janeiro, } \\
\text { Brazil }\end{array}$ & unknown & S & CeMV & {$[63]$} \\
\hline Sotalia guianensis & 2010 & Espirito Santo, Brazil & unknown & $\begin{array}{c}\text { IHC, } \\
\text { RT-PCR }\end{array}$ & CeMV NL & [6] \\
\hline
\end{tabular}


Table 1. Cont.

\begin{tabular}{|c|c|c|c|c|c|c|}
\hline $\begin{array}{l}\text { Ocean } \\
\text { Provinces/Species }\end{array}$ & Years & Countries & $\begin{array}{l}\text { Epidemiolo- } \\
\text { gical Status }\end{array}$ & Diagnosis & Virus & $\begin{array}{c}\text { Literature } \\
\text { Cited }\end{array}$ \\
\hline \multicolumn{7}{|l|}{ Eastern Pacific } \\
\hline $\begin{array}{l}\text { Lagenorhynchus } \\
\text { obscurus }\end{array}$ & 1993-1995 & Central Peru & endemic & $\mathrm{S}$ & CeMV & {$[62]^{\prime}$} \\
\hline T. truncatus & 1993-1995 & Central Peru & endemic & $\mathrm{S}$ & CeMV & {$[62]$} \\
\hline $\begin{array}{l}\text { Delphinus } \\
\text { capensis }\end{array}$ & 1993-1995 & Central Peru & endemic & $\mathrm{S}$ & CeMV & {$[62]$} \\
\hline D. delphis & 1995-1997 & $\begin{array}{l}\text { California, } \\
\text { USA }\end{array}$ & unknown & $\begin{array}{l}\text { S, IHC, } \\
\text { RT-PCR }\end{array}$ & CeMV & {$[4,75]$} \\
\hline \multicolumn{7}{|l|}{ Indopacetus } \\
\hline pacificus & 2010 & Hawaii, USA & unknown & HC, RT-PCR & BWMV & {$[5]$} \\
\hline $\begin{array}{l}\text { Physeter } \\
\text { macrocephalus }\end{array}$ & 2011 & Hawaii, USA & unknown & RT-PCR & BWMV & [121] \\
\hline \multicolumn{7}{|l|}{ Western Pacific } \\
\hline $\begin{array}{l}\text { Lagenorhynchus } \\
\text { obliquidens }\end{array}$ & 1998 & $\begin{array}{l}\text { Miyazaki, } \\
\text { Japan }\end{array}$ & unknown & IHC & unknown & [106] \\
\hline K. breviceps & 2009 & SW Taiwan & $\begin{array}{l}\text { periodic } \\
\text { mortalities }\end{array}$ & $\begin{array}{c}\text { IHC, } \\
\text { RT-PCR }\end{array}$ & DMV & {$[70]$} \\
\hline G. melas & 1997 & $\begin{array}{l}\text { Northland, } \\
\text { New Zealand }\end{array}$ & endemic & $\mathrm{S}$ & CeMV & {$[63]$} \\
\hline T. truncatus & 1997 & $\begin{array}{l}\text { Tasmania, } \\
\text { Australia }\end{array}$ & unknown & $\mathrm{S}$ & CeMV & {$[63]$} \\
\hline $\begin{array}{l}\text { Peponocephala } \\
\text { electra }\end{array}$ & 2005-2007 & NE Australia & endemic & $\mathrm{S}$ & CeMV & [90] \\
\hline Tursiops aduncus & 2005-2010 & NE Australia & unknown & $\mathrm{S}$ & CeMV & [90] \\
\hline L. hosei & 2006 & NE Australia & unknown & S & CeMV & {$[90]$} \\
\hline T. truncatus & 2009-2010 & $\begin{array}{l}\text { Queensland, } \\
\text { Australia }\end{array}$ & $\begin{array}{l}\text { periodic } \\
\text { mortalities }\end{array}$ & $\begin{array}{l}\text { S, IHC, } \\
\text { RT-PCR }\end{array}$ & DMV & {$[68,90]$} \\
\hline \multicolumn{7}{|l|}{ Indian Ocean } \\
\hline D. delphis & 1999 & $\begin{array}{l}\text { East London, } \\
\text { South Africa }\end{array}$ & unknown & $\mathrm{S}$ & CeMV & {$[63]$} \\
\hline T. aduncus & 2009 & $\begin{array}{l}\text { Western } \\
\text { Australia }\end{array}$ & $\begin{array}{l}\text { periodic } \\
\text { mortalities }\end{array}$ & IHC, RT-PCR & CeMV $N L$ & {$[7]$} \\
\hline \multicolumn{7}{|l|}{ Southern Ocean } \\
\hline T. aduncus & 2012-2013 & South Australia & unknown & IHC, RT-PCR & CeMV NL & {$[51,131]$} \\
\hline T. truncatus & 2013 & South Australia & unknown & IHC, RT-PCR & CeMV NL & {$[51,131]$} \\
\hline D. delphis & 2012-2013 & South Australia & unknown & RT-PCR & CeMV NL & {$[51,131]$} \\
\hline
\end{tabular}

\subsection{Europe}

\subsubsection{North Sea, NE Atlantic, and CE Atlantic}

In the North Sea and NE Atlantic Ocean, the first cetacean morbillivirus mortalities were detected in P. phocoena stranded along the coasts of Ireland, England and the Netherlands in 1988-1990 [22,53]. Sporadic morbillivirus infections were further observed in L. albirostris and fin whales (Balaenoptera physalus) beached in Northern Europe in 1990-2011 [34,126]. Serological surveys of stranded D. delphis and P. phocoena in the UK and the Netherlands in 1988-1999 showed that prevalence of 
DMV-seropositivity was declining over time and that only adult porpoises and dolphins were positive in 1997-1999. This suggested that the virus had not persisted as an endemic infection in these populations $[61,63]$. Similarly, with the exception of a $P$. phocoena with systemic morbillivirus infection beached in Kent, UK, in late 1990, systemic morbilliviral disease was not detected in any porpoise that stranded along the coasts of Belgium, northern France, England and Germany in 1990-2000 [132-135]. Though the number of $P$. phocoena in the North Sea and adjacent waters was theoretically large enough to sustain an endemic infection $(341,366$ individual [ $95 \%$ confidence interval $=260,000-449,000]$ in 1994 [136]), their solitary behavior likely did not favor morbillivirus transmission and maintenance in this population. The presence of high titers of DMV antibodies in the serum of a juvenile G. melas collected in the English Channel in 1996 suggested that this species could be involved in the maintenance of the virus in the NE Atlantic [61]. However, further serological surveys and molecular investigations are needed to understand the ecology of CeMV in this ocean basin.

Recently, CeMV infection was detected in Delphinidae from the CE Atlantic Ocean. A virus closely related to the PWMV strain was detected by RT-PCR in the brain of a G. macrorhynchus stranded in Tenerife, Canary Islands, Spain, in 1996 [30]. In addition, an IHC and RT-PCR retrospective survey showed that DMV caused chronic CNS disease in S. coeruleoalba and D. delphis washed ashore in the Canary Islands in the period 2002-2011 [33]. Finally, a systemic DMV infection was observed in a T. truncatus stranded in Lanzarote, Canary Islands, in 2005 [69]. Thus, at least two strains of CeMV are circulating in cetaceans from this ocean province.

\subsubsection{Mediterranean Sea}

In the Mediterranean Sea, DMV caused two well-documented outbreaks of mass mortality in S. coeruleoalba in 1990-1992 and in 2006-2008. The first outbreak started in Valencia, Spain, in July 1990 and extended to France, Italy, Greece and Morocco, ending in the spring of 1992. All age classes were affected but most dead dolphins were adults. Although precise mortality rates could not be determined, thousands of animals are thought to have died [127,137]. As an indirect measure of the impact, the mean school size in the areas most affected by the 1990-1992 outbreak significantly decreased to less than $30 \%$ of the pre-outbreak numbers [127,137]. Serological surveys carried out during and after the epidemic indicated that in 1997-1999 only adult dolphins had DMV antibodies and that the prevalence of seropositivity in mature dolphins had decreased from $100 \%(N=8)$ in 1990-1992 to 50\% $(N=6)$ in 1997-1999, but sample sizes were small [63]. This suggested that DMV had not persisted in $S$. coeruleoalba after the epidemic ended, presumably because their abundance $(117,880 \mathrm{CI}=68,379-148,000)$ in the western Mediterranean Sea [137] was too low to support endemic infection $[63,67]$. Histological and IHC surveillance further supported this hypothesis. Indeed, systemic CeMV was not detected in $50 \mathrm{~S}$. coeruleoalba stranded along the Catalonian coast in the inter-epidemic period [56]. Between October 2006 and April 2007, at least 27 morbillivirus-infected G. melas stranded along the southern Spanish Mediterranean coast and the Balearic Islands. The outbreak was first recorded in the Strait of Gibraltar area in late October 2006 and then spread to Valencia [67,88]. In early July 2007 DMV-infected $S$. coeruleoalba were observed in the Gulf of Valencia [67]. The number of animals washed ashore from July through August 2007 was similar to that recorded in 1990 during the same months. The stranding rate was also similar during each episode, with an initial low rate at the 
beginning of July and then a sharp increase in mid-August [67]. The outbreak extended to France and Italy during the following months, also affecting T. truncatus [32,138]. Mostly juveniles were affected during this mortality event, likely because adults were still protected by immunity acquired during the 1990-1992 epidemic [32,67]. The virus strains amplified by RT-PCR from tissues of S. coeruleoabalba, G. melas and T. truncatus were similar to those isolated during the 1990-1992 epidemic but not identical ([27,31,32,67,88], this paper). An estimated 200 striped dolphins died in the western Mediterranean but the total number of deaths remains unknown [67]. As well as the deaths caused by the acute infection, there were also several cases, ultimately lethal, of a chronic CNS form of infection in 1991-1994 and 2008-2011 in the western Mediterranean and in 2009-2011 in the Eastern Mediterranean [56,66,94]. In the Western Mediterranean chronic morbillivirus encephalitis represented the most common single cause of stranding and death in mature $S$. coeruleoalba in the years following a DMV epizootic [56]. These data suggest that the second DMV outbreak may also have had a negative impact on the Mediterranean S. coeruleoalba population, though to a lesser extent than the previous one. Little is known about the impacts of the outbreak on populations of the other cetacean species affected. However, Wierucka et al. [139] found that the 2006-2008 DMV epidemic lowered the survival rate of some clusters (groups of individuals that associate with each other more often than with others) of G. melas (from 0.919 (95\% CI: 0.854-0.956) to 0.547 (95\% CI: 0.185-0.866)) in the Alboran Sea and Gulf of Vera.

The $S$. coeruleoalba population density in the Gulf of Valencia $\left(0.49 \mathrm{dolphin} / \mathrm{km}^{2}\right)$ was again close to the maximum reported for this species in the Western Mediterranean in 2001-2003 [104,140]. This high population density, with a large proportion of susceptible individuals, likely favored viral transmission and permitted the start of a new epidemic when DMV was reintroduced into the population [67]. As both the 1990-1992 and 2006-2007 DMV epidemics started close to, or in, the Gibraltar Strait, it was suggested that DMV endemically infected cetaceans, possibly G. melas transmitted the infection to $S$. coeruleoalba with which they occasionally form mixed groups (Raga et al. pers. observations). The recent detection of DMV strains in S. coeruleoalba from the CE Atlantic Ocean that are almost identical to the Mediterranean strains [33] indicates that this population could also transmit the virus to the Mediterranean $S$. coeruleoalba through occasional contacts in the Strait of Gibraltar. The finding of systemic morbillivirus infection in two adult $S$. coeruleoalba stranded on the southwestern (Atlantic) coast of Spain, close to Gibraltar in 2011 and 2012 [141] further indicates that this Strait plays an important role in the epidemiology of CeMV. Environmental factors (higher sea-surface temperatures and limited prey availability), as well as fisheries interactions, inbreeding, migration, and high contaminant loads may synergistically interact to increase the severity of the disease and favor transmission between species [127,142-145]. When CeMV herd immunity significantly decreases in Mediterranean $S$. coeuruleoalba, the population will again be at risk for an epidemic. Serological surveys are needed to determine the current immune status of these dolphins and facilitate development of predictive epidemiological models.

Recently, morbilliviral RNA was detected by RT-PCR in brain and lung samples from 22 of 52 S. coeruleoalba, one of three T. truncatus and one B. physalus stranded along the Italian Tyrrhenian Sea coast during an unusual mortality event in early 2013 ([146], Di Guardo and Mazzariol, pers. observations). However, as none of the positive individuals had characteristic morbillivirus lesions and, as other infectious agents were concurrently detected in a high percentage of these individuals, 
the proximate cause of the event is still under investigation (Di Guardo and Mazzariol, pers. observations.).

\subsubsection{Black Sea}

Two D. delphis ponticus that stranded during an outbreak of mortality in Crimea in August and September 1994 had broncho-pneumonia, syncytia and lymphoid depletion [117]. Morbillivirus antigen was observed by IHC in the lungs, cerebrum, spleen and lymph nodes. However, morbillivirus RNA could only be detected in a formalin-fixed sample of a testicular fibroma by RT-PCR. There was no evidence of morbillivirus in the frozen tissues using either virus isolation or an antigen capture ELISA that had proven useful during other mortality events $[3,22,117]$. As virus isolation was negative and sequencing of the PCR products was not performed, it is unclear which morbillivirus caused the death of these dolphins. The last $S$. coeruleoalba reported to die of acute DMV infection in Greek waters was found in the spring of 1992, two years before the D. delphis ponticus mortality in the Black Sea. $S$. coeruleoalba are not known to enter the Turkish Strait Systems (Bosphorus, Marmara Sea and Dardanelles) where D. delphis ponticus are commonly seen, and are absent from the Black Sea [147]. D. delphis ponticus have also not been reported in Aegean waters [147]. Thus, a link between the 1990-1992 morbillivirus outbreak in Mediterranean S. coeruleoalba and the morbillivirus infection in the two D. delphis ponticus stranded in Crimea is unclear. Whether the morbillivirus was in fact CeMV, originating in the Mediterranean, or another morbillivirus should be further examined.

\subsection{North America}

There have been several die-offs in coastal T. truncatus populations from the Gulf of Mexico and the Atlantic coast of the US since $1982[25,57,80,92,130,148]$.

\subsubsection{Atlantic Coast}

From January to May of 1982, 43 carcasses were recovered in the Indian River Lagoon System (IRL), Florida, among a community estimated at 211 individuals [129]. Serological data indicated that this outbreak was likely due to a morbillivirus infection and contact with endemically infected species such as offshore T. truncatus was hypothesized to be the source of infection for the event [25]. Further serological studies performed on samples collected from 2003-2007 indicated that IRL dolphins born after the 1982 mortality had antibodies to a DMV-like virus, indicating exposure and infection, though no outbreaks or associated deaths were documented after 1982 [64].

From June 1987 to May of 1988, CeMV infected both inshore and estuarine T. truncatus, starting from New Jersey and, eventually, reaching Florida [25,57,92,148]. This mass mortality was associated with the stranding of at least $645 \mathrm{~T}$. truncatus [148]. DMV infection was also detected in a S. coeruleoalba, indicating that multiple species were affected during that outbreak [92]. Starting in July 2013, another outbreak affected these populations along the Atlantic coast from New York through northern Florida and is currently ongoing [71]. Over 1500 T. truncatus have died and the majority of the individuals tested by RT-PCR have been positive for DMV [71,130]. Contacts between inshore T. truncatus and offshore species (offshore T. truncatus, Globicephala sp., S. coeruleoalba, L. hosei, 
and false killer whales (Pseudorca crassidens)) in which CeMV is endemic [23-25] may have been the sources of infection for the 1987-88 and 2013-2014 outbreaks. Seasonal overlap between resident coastal T. truncatus stocks at certain times of the year, and migration of the coastal migratory stock, may have favored transmission of the disease down the coast [149]. A serological survey performed on samples collected from live capture-released coastal and estuarine T. truncatus along the east coast of the US in 1999-2004 indicated that the seroprevalence decreased over the years of the study, suggesting that CeMV did not persist as an endemic infection in these populations, as had been predicted $[25,26]$. Therefore, population immunity likely continued to decrease over time leading to increased numbers of susceptible individuals and resulting in the 2013-2014 epidemic. The role of environmental and anthropogenic factors in this mortality and the population impacts is being investigated [71].

\subsubsection{Gulf of Mexico}

In 1993-1994, CeMV caused another outbreak of mortality, this time in a population of T. truncatus from the Gulf of Mexico, spanning from Florida (Panama City) to Texas [92,150]. A total of 171 specimens were retrieved from the entire Texas coast in March and April 1994 [151]. About a quarter of 34 dolphins sampled in Matagorda Bay in 1992 had CeMV antibodies, indicating that this community/population had been exposed to the virus before the 1993-1994 outbreak occurred [25].

\subsubsection{North Pacific}

Morbillivirus infection was detected by RT-PCR in a juvenile male I. pacificus stranded at Hana, Maui in March 2010, following traumatic maxillary and mandibular bone fractures [5]. The whale had chronic encephalitis and was also concurrently infected by an alphaherpesvirus [5]. Though morbillivirus RNA was detected by RT-PCR in samples of the lungs, spleen, thymus, and lymph nodes the juvenile did not have any typical morbillivirus lesions in these organs [5]. This may reflect prolonged persistence of morbilliviral RNA following acute infection, as described for MV [93] but further analyses are necessary to confirm this hypothesis. The virus represents a new strain of CeMV-1, tentatively named beaked whale morbillivirus. BWMV was also detected by RT-PCR in the tracheobronchial lymph node and spleen of a neonate P. macrocephalus beached on the island of Oahu, Hawaii, in May 2011. However, typical morbillivirus lesions were not detected in this individual [121].

Six of 18 D. delphis that stranded along the coast of California from August 1995 through August 1997 had serum antibodies against DMV. Morbilliviral RNA was detected in the normal spleen and heart of two seropositive dolphins that did not show any typical morbillivirus lesions and in the brain of a third dolphin that suffered mild lymphocytic meningoencephalitis [75]. Together, these data indicate that CeMV strains are circulating in the North Pacific.

\subsection{South America}

Although CeMV infection had already been detected by serology in gregarious odontocetes from Peru, Argentina and Brazil in the late 1990s ([62,63]; Table 1), morbillivirus mortalities were not observed until recently [6]. A new lineage of CeMV was detected in an emaciated S. guianensis calf washed ashore dead at Guriri, Espírito Santo State, Brazil, in November 2010 with marked lymphoid 
depletion, interstitial pneumonia, and meningoencephalitis [6]. The S. guianensis community off Guriri may be related to the Abrolhos Bank population that concentrates around the estuaries of Caravelas (estimated at 57-124 individuals) and Doce rivers [152,153]. Though S. guianensis have not been observed mixing with other cetacean species in this region, it is sympatric with the rough-toothed dolphin (Steno bredanensis), T. truncatus, the humpback whale (Megaptera novaeangliae) and the southern right whale (Eubalaena australis) [154,155]. Interactions between these species may have resulted in the infection of the $S$. guianensis calf. Preliminary IHC studies suggested that morbilliviruses have infected other cetacean species along the Brazilian coast [156].

\subsection{Asia and Australasia}

\subsubsection{Asia}

CeMV infection was detected by serology, IHC and RT-PCR in a stranded L. obliquidens from Japan, in a pygmy sperm whale (Kogia breviceps) beached in Taiwan and in a captive T. aduncus from Taiwan $[63,70,106]$. The L. obliquens was diagnosed with a chronic persistent morbillivirus encephalitis while the $K$. breviceps had a systemic, acute infection [70,106]. Partial sequence of the P gene of the K. breviceps virus had 97.6\% similarity with DMV. The T. aduncus had very high titers against DMV likely acquired after an infection developed while still in the wild [63]. Though these data indicate that CeMV is present in odontocetes from the Northwest Pacific, mass mortalities were not reported in this ocean basin. Further investigations are necessary to determine the distribution of virus, the identity of strains and susceptibility of hosts in this region.

\subsubsection{Australasia}

Serological data indicate that CeMV infects several cetacean species from the waters of northeastern Australia, Tasmania and New Zealand and that it is possibly endemic in G. melas and P. electra, with evidence of circulation in this region as long ago as 1985 [63,90]. On Australia's Indian Ocean coast, CeMV infection was diagnosed in two T. aduncus from the Swan River, Western Australia that died during an unusual mortality event involving a small resident community of $~ 25$ individuals in June 2009 [7]. These deaths were soon followed by morbillivirus associated mortalities in two immature offshore T. truncatus in Queensland, Eastern Australia [68,90]. One was found dead on North Stradbroke Island in 2009, the other beached on Fraser Island in 2010 [68,90]. The Queensland T. truncatus were infected by a virus closely related to the DMV strain isolated in Europe and the USA and exhibited classical acute infection [68,90]. However, the Western Australia T. aduncus had an unusual form of CeMV characterized by severe lymphoid depletion and massive opportunistic infections and were infected by a strain of CeMV-2 ([7], this paper). Another morbillivirus outbreak was subsequently reported in T. aduncus and T. truncatus from South Australia in March-September 2013 [51,131]. Preliminary sequencing data suggest that the Western Australia and South Australia morbilliviruses are more similar to each other than either are to the Queensland strain (J. Wang, pers. observations). Together these data suggest that CeMV-1 and CeMV-2 are widespread in the waters of Australasia and could cause more mortalities in inshore and estuarine dolphins, in addition to offshore dolphins. 


\section{Conclusions}

Significant progress in our understanding of the epidemiology, molecular biology and pathogenesis of CeMV have been made since PMV and DMV were first detected in small odontocetes in European waters in 1988-1992. Large herds of gregarious species were found to be the likely reservoirs and sources of CeMV infection to susceptible species in the Atlantic and Pacific Oceans [23-25,61-63,90]. New species and lineages of CeMV have been recently discovered [5-7]. Several techniques have been developed to optimize the diagnosis of CeMV infection, to differentiate the strains and to reduce the possibility of cross-contamination [16,20,55]. Serological assessment may enable prediction of future outbreaks [157]. The development of Next Generation Sequencing technologies has greatly enhanced the detection and genetic characterization across all forms of life [158]. To date, such technologies have not yet been applied to morbillivirus infections of aquatic mammals although they recently enabled an assessment of the evolution of ruminant morbilliviruses [159] and their application to cetacean morbilliviruses may allow a greater understanding of their evolution. Such studies may, where sampling permits, enable the use of genetic data to trace transmission routes between cetacean species and indicate key interactions between species that could lead to significant outbreak events. Standard sampling and preservation protocols should be used during suspected morbillivirus outbreaks and complete genomes of CeMV strains and lineages should be sequenced [19]. The recent discoveries of several new morbilli-related viruses in bats [160], as well a potentially novel feline morbillivirus representing a basal divergence in the genus [11], are likely to lead to a revision of the phylogeny and understanding of the evolution of morbilliviruses. Identification of the SLAM cell receptor in several cetacean species [9,13] represents a major step in our understanding of the pathogenesis of CeMV infection, especially with regard to susceptibility and transmission to non-classical hosts, such as pinnipeds $[9,13,161,162]$. Further studies should confirm whether the SLAM cell receptor is indeed the primary immune receptor for CeMV, as is the case for other studied morbilliviruses, and should look for the nectin4 epithelial cell receptor and other cell receptors in cetaceans. Further studies are also warranted to delineate the host responses to CeMV strains and lineages, and the factors that determine the outcome of infection in cetaceans. Mathematical models should be developed to examine the long-term dynamic consequences of the epidemics on odontocete populations and to predict the risk of epidemics, as has been done for PDV in harbor seals (Phoca vitulina) [157,163]. The concurrent use of the different diagnostic techniques in the context of an integrative approach that includes epidemiological parameters, life history of the affected species and environmental parameters should provide a better and more complete picture of the ecology and evolution of CeMV.

\section{Acknowledgements}

We kindly thank Rik de Swart for inviting us to participate to this special issue, K Van Waerebeek and Jason Baker for their constructive comments on this manuscript, two anonymous reviewers for their useful comments and suggestions and Rob Deaville for the image of a harbor porpoise. This work emerged from a meeting funded by the RAPIDD program of the Science and Technology Directorate, Department of Homeland Security and the Fogarty International Center, National Institutes of Health. N. Stephens thanks the Swan River Trust and the Department of Parks and Wildlife for their support. 


\section{Author Contributions}

M-F Van Bressem designed paper outlines and Figures 1 and 3, did the main writing and literature review; P. Duignan helped to design the ms outlines, contributed to the writing of the introduction, diagnosis, pathology and epidemiology sections, reviewed and improved earlier drafts, made many helpful suggestions, facilitated access to the T. aduncus morbillivirus and helped with literature search; A. Banyard build the phylogenetic tree (Figure 2), contributed to the virology section and conclusions, made useful comments and reviewed several drafts of the manuscript; F. Gulland organized the marine mammal morbillivirus workshop in Princeton, USA in August 2014, contributed to draw the paper outlines, made helpful suggestions and reviewed various drafts of the manuscript; K. Colegrove contributed to the epidemiology and pathology sections, reviewed various drafts of the manuscript and provided unpublished information; D. Fauquier and T. Goldstein contributed to the epidemiology section, reviewed several drafts of the manuscript and provided unpublished information; O. Nielsen contributed to the receptor, virology and diagnosis sections and reviewed drafts of the manuscript; S. De Guise wrote the paragraph 'Immune function and CeMV infections', reviewed drafts of the manuscript and provided unpublished information; J. Saliki contributed to the diagnosis and virology sections, made helpful suggestions and reviewed drafts of the manuscript; G. Di Guardo, M. Domingo, S. Mazzariol, A. Fernandez, and E. Sierra contributed to the pathology sections and to Figures 1 and 3, reviewed drafts of the manuscript and made useful comments; B. Stone, I. Tomo and N. Stephens contributed to the epidemiology and virology sections and to Figures 1 and 3, made useful comments and allowed access the Australian dolphin morbilliviruses; K. Groch contributed to the epidemiology and virology sections, greatly helped with the figures, formatting of the manuscript and literature, reviewed drafts of the manuscript and provided unpublished data; T. Raga contributed to the introduction and epidemiology section and Figure 1, made helpful suggestions and reviewed drafts of the manuscript; J. Wellehan contributed to the introduction, receptors and virology sections and conclusions, reviewed an advanced version of the manuscript and made helpful comments; T. Waltzek reviewed an advanced draft of the manuscript and made useful comments; J. Wang provided the sequences of the Australian $T$. aduncus morbilliviruses, reviewed an advanced draft of the manuscript and made useful comments; A. Hall reviewed an advanced draft of the manuscript and made useful comments; B. Grenfell organized the marine mammal morbillivirus workshop in Princeton in August 2014, contributed to the epidemiology section and reviewed an advanced draft of the manuscript; A. Dobson made useful comments on the manuscript and reviewed an advanced draft of the manuscript; P. Jepson reviewed an earlier version of the manuscript and provided Figure 1C.; B. Jensen provided Figure $1 \mathrm{G}$ and made useful comments; T.K. Rowles organized the marine mammal morbillivirus workshop in Princeton in August 2014, revised drafts of the manuscript and made useful suggestions; M. Barbieri and S.E. Morris participated to the workshop, facilitated access to CeMV literature and made constructive comments; T. Kuiken provided literature.

\section{Conflicts of Interest}

The authors declare no conflict of interest. 


\section{References and Notes}

1. McCullough, S.J.; McNeilly, F.; Allan, G.M.; Kennedy, S.; Smyth, J.A.; Cosby, S.L.; McQuaid, S.; Rima, B.K. Isolation and characterisation of a porpoise morbillivirus. Arch. Virol. 1991, 118, 247-252.

2. Domingo, M.; Ferrer, L.; Pumarola, M.; Marco, A.; Plana, J.; Kennedy, S.; McAliskey, M.; Rima, B.K. Morbillivirus in dolphins. Nature 1990, 348, 21.

3. Van Bressem, M.-F.; Visser, I.K.G.; van de Bildt, M.W.; Teppema, J.S.; Raga, J.A.; Osterhaus, A.D.M.E. Morbillivirus infection in Mediterranean striped dolphins (Stenella coeruleoalba). Vet Rec. 1991, 129, 471-472.

4. Taubenberger, J.K.; Tsai, M.M.; Atkin, T.J.; Fanning, T.G.; Krafft, A.E.; Moeller, R.B.; Kodsi, S.E.; Mense, M.G.; Lipscomb, T.P. Molecular genetic evidence of a novel morbillivirus in a long-finned pilot whale (Globicephala melas). Emerg. Infect. Dis. 2000, 6, 42-45.

5. West, K.L.; Sanchez, S.; Rotstein, D.; Robertson, K.M.; Dennison, S.; Levine, G.; Davis, N.; Schofield, D.; Potter, C.W.; Jensen, B. A Longman's beaked whale (Indopacetus pacificus) strands in Maui, Hawaii, with first case of morbillivirus in the central Pacific. Mar. Mamm. Sci. 2013, 29, 767-776.

6. Groch, K.R.; Colosio, A.C.; Marcondes, M.C.; Zucca, D.; Díaz-Delgado, J.; Niemeyer, C.; Marigo, J., Brandão, P.E., Fernández, A.; Luiz Catão-Dias, J. Novel cetacean morbillivirus in Guiana dolphin, Brazil. Emerg. Infect. Dis. 2014, 20, 511-513.

7. Stephens., N.; Duignan, P.J.; Wang, J.; Bingham, J.; Finn, H.; Bejder, L.; Patterson, A.P.; Holyoake, C. Cetacean morbillivirus in coastal Indo-Pacific bottlenose dolphins, Western Australia. Emerg. Infect. Dis. 2014, 20, 666-670.

8. Barrett, T. Morbillivirus infections, with special emphasis on morbilliviruses of carnivores. Vet. Microbiol. 1999, 69, 3-13.

9. Ohishi, K.; Suzuki, R.; Maruyama, T. Host-Virus Specificity of the Morbillivirus Receptor, SLAM, in Marine Mammals: Risk Assessment of infection based on three-dimensional models. In New Approaches to the Study of Marine Mammals; Romero, A., Keith, E.O., Eds.; InTech: Rijeka, Croatia, 2012; pp. 183-204.

10. Hall, A.J. Morbilliviruses in marine mammals. Trends Microbiol. 1995, 3, 4-9.

11. Woo, P.C.; Lau, S.K.; Wong, B.H.; Fan, R.Y.; Wong, A.Y.; Zhang, A.J.; Wu, Y.; Choi, G.K.; Li, K.S.; Hui, J.; et al. Feline morbillivirus, a previously undescribed paramyxovirus associated with tubulointerstitial nephritis in domestic cats. Proc. Natl. Acad. Sci. USA 2012, 109, 5435-5440.

12. Delpeut, S.; Noyce, R.S.; Richardson, C.D. The tumor-associated marker, PVRL4 (nectin-4), is the epithelial receptor for morbilliviruses. Viruses 2014, 6, 2268-2286.

13. Shimizu, Y.; Ohishi, K.; Suzuki, R.; Tajima, Y.; Yamada, T.; Kakizoe, Y.; Bando, T.; Fujise, Y.; Taru, H.; Murayama, T.; et al. Amino acid sequence variations of signaling lymphocyte activation molecule and mortality caused by morbillivirus infection in cetaceans. Microbiol. Immunol. 2013, 57, 624-632.

14. Barrett, T.; Blixenkrone-Møller, M.; di Guardo, G.; Domingo, M.; Duignan, P.; Hall, A.; Mamaev, L.; Osterhaus, A.D.M.E. Morbilliviruses in aquatic mammals: Report on round table discussion. Vet. Microbiol. 1995, 44, 261-265. 
15. Osterhaus, A.D.M.E.; de Swart, R.L.; Vos, H.W.; Ross, P.S.; Kenter, M.J.H.; Barrett, T. Morbillivirus infections of aquatic mammals: Newly identified members of the genus. Vet. Microb. 1995, 44, 219-227.

16. Barrett, T.; Visser, I.K.G.; Mamaev, L.; Goatley, L.; van Bressem, M.-F.; Osterhaus, A.D.M.E. Dolphin and porpoise morbilliviruses are genetically distinct from phocine distemper virus. Virology 1993, 193, 1010-1012.

17. Blixenkrone-Möller, M.; Bolt, G.; Gottschalk, E.; Kenter, M. Comparative analysis of the gene encoding the nucleocapsid protein of dolphin morbillivirus reveals its distant evolutionary relationship to measles virus and ruminant morbilliviruses. J. Gen. Virol. 1994, 75, 2829-2834.

18. Bolt, G.; Blixenkrone-Möller, M.; Gottschalk, E.; Wishaupt, R.G.A.; Welsh, M.J.; Earle, P.J.A.; Rima, B.K. Nucleotide and deduced amino acid sequences of the matrix (M) and fusion (F) protein genes of cetacean morbilliviruses isolated isolated from a porpoise and a dolphin. Virus Res. 1994, 34, 291-304.

19. Rima, B.K.; Collin, A.M.; Earle, J.A. Completion of the sequence of a cetacean morbillivirus and comparative analysis of the complete genome sequences of four morbilliviruses. Virus Genes. 2005, 30, 113-119.

20. Banyard, A.C.; Grant, R.J.; Romero, C.H.; Barrett, T. Sequence of the nucleocapsid gene and genome and antigenome promoters for an isolate of porpoise morbillivirus. Virus Res. 2008, 132, 213-219.

21. Van Bressem, M.-F.; Visser, I.K.G.; de Swart, R.L.; Örvell, C.; Stanzani, L.; Androukaki, E.; Siakavara, K.; Osterhaus, A.D.M.E. Dolphin morbillivirus in different parts of the Mediterranean Sea. Arch. Virol. 1993, 129, 235-242.

22. Visser, I.K.G.; van Bressem, M.-F.; de Swart, R.L.; van de Bildt, M.W.G.; Vos, H.W.; van der Heijden, R.W.J.; Saliki, J.T.; Örvell, C.; Kitching, P.; Kuiken, T.; et al. Characterization of morbilliviruses isolated from dolphins and porpoises in Europe. J. Gen. Virol. 1993, 74, 631-641.

23. Duignan, P.J.; House, C.; Geraci, J.R.; Early, G.; Copland, H.G.; Walsh, M.T.; Bossart, G.D.; Cray, C.; Sadove, S.; St. Aubin, D.J.; et al. Morbillivirus infection in two species of pilot whales (Globicephala sp.) from the western Atlantic. Mar. Mamm. Sci. 1995, 11, 150-162.

24. Duignan, P.J.; House, C.; Geraci, J.R.; Duffy, N.; Rima, B.K.; Walsh, M.T.; Early, G.; St Aubin, D.J.; Sadove, S.; Koopman, H.; et al. Morbillivirus infection in cetaceans of the western Atlantic. Vet. Microbiol. 1995, 44, 241-249.

25. Duignan, P.J.; House, C.; Ode11, D.K.; Wells, R.S.; Hansen, W.; Walsh, M.T.; St. Aubin, D.J.; Rima, B.K.; Geraci, J.R. Morbillivirus in bottlenose dolphins: Evidence for recurrent epizootics in the western Atlantic and Gulf of Mexico. Mar. Mamm. Sci. 1996, 12, 499-515.

26. Rowles, T.R.; Schwacke, L.S.; Wells, R.S.; Saliki, J.T.; Hansen, L.; Hohn, A.; Townsend, F.; Sayre, R.A.; Hall, A.J. Evidence of susceptibility to morbillivirus infection in cetaceans from the United States. Mar. Mamm. Sci. 2011, 27, 1-19.

27. Banyard, A.C.; Tiwari, A.; Barrett, T. Morbillivirus infection in pilot whales: Strict protein requirement drives genetic conservation. Arch. Virol. 2011, 156, 1853-1839.

28. Van de Bildt, M.W.; Kuiken, T.; Osterhaus, A.D.M.E. Cetacean morbilliviruses are phylogenetically divergent. Arch. Virol. 2005, 150, 577-583. 
29. King, A.M.Q.; Adams, M.J.; Carstens, E.B.; Lefkowitz, E.J. Virus Taxonomy: Classification and Nomenclature of Viruses: Ninth Report of the International Committee on Taxonomy of Viruses; Elsevier/Academic Press: London, UK, 2011.

30. Bellière, E.N.; Esperón, F.; Fernández, A.; Arbelo, M.; Muñoz, M.J.; Sánchez-Vizcaíno, J.M. Phylogenetic analysis of a new Cetacean morbillivirus from a short-finned pilot whale stranded in the Canary Islands. Res. Vet. Sci. 2011, 90, 324-328.

31. Bellière, E.N.; Esperón, F.; Sánchez-Vizcaíno, J.M. Genetic comparison among dolphin morbillivirus in the 1990-1992 and 2006-2008 Mediterranean outbreaks. Infect. Genet. Evol. 2011, 11, 1913-1920.

32. Keck, N.; Kwiatek, O.; Dhermain, F.; Dupraz, F.; Boulet, H.; Danes, C.; Laprie, C.; Perrin, A.; Godenir, J.; Micout, L.; et al. Resurgence of Morbillivirus infection in Mediterranean dolphins off the French coast. Vet. Rec. 2010, 166, 654-655.

33. Sierra, E.; Sánchez, S.; Saliki, J.T.; Blas-Machado, U.; Arbelo, M.; Zucca, D.; Fernández A. Retrospective study of etiologic agents associated with nonsuppurative meningoencephalitis in stranded cetaceans in the Canary Islands. J. Clin. Microbiol. 2014, 52, 2390-2397.

34. Van Elk, C.E.; van de Bildt, M.W.; Jauniaux, T.; Hiemstra, S.; van Run, P.R.; Foster, G.; Meerbeek, J.; Osterhaus, A.D.M.E.; Kuiken, T. Is Dolphin Morbillivirus Virulent for White-Beaked Dolphins (Lagenorhynchus albirostris)? Vet. Pathol. 2014, doi:10.1177/0300985813516643.

35. Tamura, K.; Peterson, D.; Peterson, N.; Stecher, G.; Nei, M.; Kumar, S. MEGA5: Molecular evolutionary genetics analysis using maximum likelihood, evolutionary distance, and maximum parsimony methods. Mol. Biol. Evol. 2011, 28, 2731-2739.

36. Milinkovitch, M.C.; Thewissen, J.G.M. Even-toed fingerprints on whale ancestry. Nature 1997, 388, 622-624.

37. Nikaido, M.; Rooney, A.P.; Okada, N. Phylogenetic relationships among cetartiodactyls based on insertions of short and long interpersed elements: Hippopotamuses are the closest extant relatives of whales. Proc. Natl. Acad. Sci. USA 1999, 96, 10261-10266.

38. Barrett, T.; Rossiter, P.B. Rinderpest: The disease and its impact on humans and animals. Adv. Virus Res. 1999, 53, 89-110.

39. Kumar, N.; Maherchandani, S.; Kashyap, S.K.; Singh, S.V.; Sharma, S.; Chaubey, K.K.; Ly, H. Peste des petits ruminants virus infection of small ruminants: A comprehensive review. Vet. Med. Int. 2014, 6, 2287-2327.

40. Nollens, H.H.; Ruiz, C.; Walsh, M.T.; Gulland, F.M.D.; Bossart, G.; Jensen, E.E.; McBain, J.F.; Wellehan, J.F.X. Cross- reactivity of immunoglobulin G of whales and dolphins correlates with evolutionary distance of cytochrome B genes. Clin. Vacc. Immunol. 2008, 15, 1547-1554.

41. Wild, T.F.; Malvoisin, E.; Buckland, R. Measles virus: Both the haemagglutinin and fusion glycoproteins are required for fusion. J. Gen. Virol. 1991, 72, 439-442.

42. Melia, M.M.; Earle, J.P.; Abdullah, H.; Reaney, K.; Tangy, F.; Cosby, S.L. Use of SLAM and PVRL4 and identification of pro-HB-EGF as cell entry receptors for wild type phocine distemper virus. PLoS One 2014, 9, e106281.

43. Tatsuo, H.; Ono, N.; Yanagi, Y. Morbilliviruses use signaling lymphocyte activation molecules (CD150) as cellular receptors. J. Virol. 2001, 75, 5842-5850. 
44. Muhlebach, M.D.; Mateo, M.; Sinn, P.L.; Prufer, S.; Uhlig, K.M.; Leonard, V.H.; Navaratnarajah, C.K.; Frenzke, M.; Wong, X.X.; Sawatsky, B.; et al. Adherens junction protein nectin-4 is the epithelial receptor for measles virus. Nature 2011, 480, 530-533.

45. Noyce, R.S.; Bondre, D.G.; Ha, M.N.; Lin, L.T.; Sisson, G.; Tsao, M.S.; Richardson, C.D. Tumor cell marker PVRL4 (nectin 4) is an epithelial cell receptor for measles virus. PLoS Pathog. 2011, 7, e1002240.

46. Watanabe, A.; Yoneda, M.; Ikeda, F.; Terao-Muto, Y.; Sato, H.; Kai, C. CD147/EMMPRIN acts as a functional entry receptor for measles virus on epithelial cells. J. Virol. 2010, 84, 4183-4193

47. Baron, M.D. Wildtype rinderpest virus uses SLAM (CD150) as its receptor. J. Gen. Virol. 2005, 86, 1753-1787.

48. Adombi, C.M.; Lelenta, M.; Lamien, C.E.; Shamaki, D.; Koffi, Y.M.; Traoré, A.; Silber, R.; Couacy-Hymann, E.; Bodjo, S.C.; Djaman, J.A.; et al. Monkey CV1 cell line expressing the sheep-goat SLAM protein: A highly sensitive cell line for the isolation of peste des petits ruminants virus from pathological specimens. J. Virol. Methods 2011, 173, 306-313.

49. Ono, N.; Tatsuo, H.; Tanaka, K.; Minagawa, H.; Yanagi, Y. V domain of human SLAM (CDw150) is essential for its function as a measles virus receptor. J. Virol. 2001, 75, 1594-1600.

50. Bieringer, M.; Han, J.W.; Kendl, S.; Khosravi, M.; Plattet, P.; Schneider-Schaulies, J. Experimental adaptation of wild-type canine distemper virus (CDV) to the human entry receptor CD150. PLoS One 2013, 8, e57488.

51. Kemper, M.C.; Woolford, L.; Tomo, I.; Dickason, C.; Bastianello, S.; Gibbs, S.; Kelly, D.; Wang, J.; Bingham, J. Abnormally high dolphin mortalities linked to Morbillivirus in South Australia. In Proceedings of the 20 Biennial Conference on the Biology of Marine Mammals, Dunedin, New Zealand, 9-13 December 2013.

52. Van Bressem, M.-F.; Raga, J.-A.; di Guardo, G.; Jepson, P.D.; Duignan, P.J.; Siebert, U.; Barrett, T.; Santos, M.C.; Moreno, I.B.; Siciliano, S.; et al. Emerging infectious diseases in cetaceans worldwide and the possible role of environmental stressors. Dis. Aquat. Org. 2009, 86, $143-157$.

53. Kennedy, S.; Smyth, J.A.; Cush, P.F.; McCullough, S.J.; Allan, G.M.; McQuaid, S. Viral distemper now found in porpoises. Nature 1988, 336, 21.

54. Kennedy, S.; Smyth, J.A.; Cush, P.F.; McAliskey, M.; McCullough, S.J.; Rima, B.K. Histopathologic and immunocytochemical studies of distemper in harbor porpoises. Vet. Pathol. 1991, 28, 1-7.

55. Grant, R.J.; Banyard, A.C.; Barrett, T.; Saliki, J.T.; Romero, C.H. Real-time RT-PCR assays for the rapid and differential detection of dolphin and porpoise morbilliviruses. J. Virol. Methods. 2009, 156, 117-123.

56. Soto, S.; Alba, A.; Ganges, L.; Vidal, E.; Raga, J.A.; Alegre, F.; González, B.; Medina, P.; Zorrilla, I.; Martínez, J. Post-epizootic chronic dolphin morbillivirus infection in Mediterranean striped dolphins Stenella coeruleoalba. Dis. Aquat. Organ. 2011, 96, 187-194.

57. Lipscomb, T.P.; Schulman, F.Y.; Moffett, D.; Kennedy, S. Morbilliviral disease in Atlantic bottlenose dolphins (Tursiops truncatus) from the 1987-1988 epizootic. J. Wildl. Dis. 1994, 30, $567-557$. 
58. Di Guardo, G.; Agrimi, U.; Morelli, L.; Cardeti, G.; Terracciano, G.; Kennedy, S. Post mortem investigations on cetaceans found stranded on the coasts of Italy between 1990 and 1993. Vet. Rec. 1995, 136, 439-442.

59. Domingo, M.; Visa, J.; Pumarola, M.; Marco, A.; Ferrer, L.; Rabanal, R.; Kennedy, S. Pathologic and immunocytochemical studies of morbillivirus infection in striped dolphins (Stenella coeruleoalba). Vet. Pathol. 1992, 29, 1-10.

60. Duignan, P.J.; Geraci, J.R.; Raga, J.A.; Calzada, N. Pathology of morbillivirus infection in striped dolphins (Stenella coeruleoalba) from Valencia and Murcia, Spain. Can. J. Vet. Res. 1992, 56, 242-248.

61. Van Bressem, M.-F.; Jepson, P.; Barrett, T. Further insight on the epidemiology of cetacean morbillivirus in the northeastern Atlantic. Mar. Mamm. Sci. 1998, 14, 605-613.

62. Van Bressem, M-F.; van Waerebeek,K.; Fleming, M.; Barrett, T. Serological evidence of morbillivirus infection in small cetaceans from the Southeast Pacific. Vet. Microb. 1998, 59, 89-98.

63. Van Bressem, M-F.; van Waerebeek, K.; Jepson, P.D.; Raga, J.A.; Duignan, P.J.; Nielsen, O.; di Beneditto, A.P.; Siciliano, S.; Ramos, R.; Kant, W.; et al. An insight into the epidemiology of dolphin morbillivirus worldwide. Vet. Microb. 2001, 81, 287-304.

64. Bossart, G.D.; Reif, J.S.; Schaefer, A.M.; Goldstein, J.; Fair, P.A.; Saliki, J.T. Morbillivirus infection in free-ranging Atlantic bottlenose dolphins (Tursiops truncatus) from the Southeastern United States: Seroepidemiologic and pathologic evidence of subclinical infection. Vet. Microbiol. 2010, 143, 160-166.

65. Bossart, G.D.; Romano, T.A.; Peden-Adams, M.M.; Schaefer, A.; McCulloch, S.; Goldstein, J.D.; Rice, C.D.; Saliki, J.T.; Fair, P.A.; Reif, J.S. Clinicoimmunopathologic findings in atlantic bottlenose dolphins Tursiops truncatus with positive cetacean morbillivirus antibody titers. Dis. Aquat. Organ. 2011, 97, 103-112.

66. Di Guardo, G.; di Francesco, C.E.; Eleni, C.; Cocumelli, C.; Scholl, F.; Casalone, C.; Peletto, S.; Mignone, W.; Tittarelli, C.; di Nocera, F.; et al. Morbillivirus infection in cetaceans stranded along the Italian coastline: Pathological, immunohistochemical and biomolecular findings. Res. Vet. Sci. 2013, 94, 132-137.

67. Raga, J.A.; Banyard, A.; Domingo, M.; Corteyn, M.; Van Bressem, M-F.; Fernández, M.; Aznar, F.J.; Barrett, T. Dolphin morbillivirus epizootic resurgence, Mediterranean Sea. Emerg. Infect. Dis. 2008, 14, 471-473.

68. Stone, B.M.; Blyde, D.J.; Saliki, J.T.; Blas-Machado, U.; Bingham, J.; Hyatt, A.; Wang, J.; Payne, J.; Crameri, S. Fatal cetacean morbillivirus infection in an Australian offshore bottlenose dolphin (Tursiops truncatus). Aust. Vet. J. 2011, 89, 452-457.

69. Sierra, E.; Zucca, D.; Arbelo, M.; García-Álvarez, N.; Andrada, M.; Déniz, S.; Fernández, A. Fatal systemic morbillivirus infection in bottlenose dolphin, Canary Islands, Spain. Emerg. Infect. Dis. 2014, 20, 269-271.

70. Yang, W.C.; Pang, V.F.; Jeng, C.R.; Chou, L.S.; Chueh, L.L. Morbilliviral infection in a pygmy sperm whale (Kogia breviceps) from Taiwanese waters. Vet. Microbiol. 2006, 116, 69-76. 
71. NOAA. 2013-2014 Bottlenose Dolphin Unusual Mortality Event in the Mid-Atlantic. 2014. Available online: http://www.nmfs.noaa.gov/pr/health/mmume/midatldolphins2013.html (accessed on 28 August 2014).

72. Nielsen, O.; Smith, G.; Weingartl, H.; Lair, S.; Measures, L. Use of a SLAM transfected Vero cell line to isolate and characterize marine mammal morbilliviruses using an experimental ferret model. J. Wildl. Dis. 2008, 44, 600-611.

73. Orvell, C.; Blixenkrone-Möller, M.; Svansson, V.; Have, P. Immunological relationships between phocid and canine distemper virus studied with monoclonal antibodies. J. Gen. Virol. 1990, 71, 2085-2092.

74. Saliki, J.T.; Lehenbauer, T.W. Monoclonal antibody-based competitive enzyme-linked immunosorbent assay for detection of morbillivirus antibody in marine mammal sera. J. Clin. Microbiol. 2001, 39, 1877-1881.

75. Reidarson, T.H.; McBain, J.; House, C.; King, D.P.; Stott, J.L.; Krafft, A., Taubenberger, J.K.; Heyning, J.; Lipscomb, T.P. Morbillivirus infection in stranded common dolphins from the Pacific Ocean. J. Wildl. Dis. 1998, 34, 771-776.

76. Lindmark, R.; Thorén-Tolling, K.; Sjöquist, J. Binding of immunoglobulins to protein A and immunoglobulin levels in mammalian sera. J. Immunol. Methods. 1983, 62, 1-13.

77. Grant, R.J.; Kelley, K.L.; Maruniak, J.E.; Garcia-Maruniak, A.; Barrett, T.; Manire, C.A.; Romero, C.H. Expression from baculovirus and serological reactivity of the nucleocapsid protein of dolphin morbillivirus. Vet. Microbiol. 2010, 143, 384-388.

78. Nielsen, O.; Stewart, R.E.; Measures, L.; Duignan, P.; House, C. A morbillivirus antibody survey of Atlantic walrus, narwhal and beluga in Canada. J. Wildl. Dis. 2000, 36, 508-517.

79. Duignan, P.J.; Nielsen, O.; House, C.; Kovacs, K.M.; Duffy, N.; Early, G.; Sadove, S.; St Aubin, D.J.; Rima, B.K.; Geraci, J.R. Epizootiology of morbillivirus infection in harp, hooded, and ringed seals from the Canadian Arctic and western Atlantic. J. Wildl. Dis. 1997, 33, 7-19.

80. Krafft, A.; Lichy, J.H.; Lipscomb, T.P.; Klaunberg, B.A.; Kennedy, S.; Taubenberger, J.K. Postmortem diagnosis of morbillivirus infection in bottlenose dolphins (Tursiops truncatus) in the Atlantic and Gulf of Mexico epizootics by polymerase chain reaction-based assay. J. Wildl. Dis. 1995, 31, 410-415.

81. Rubio-Guerri, C.; Melero, M.; Rivera-Arroyo, B.; Bellière, E.N.; Crespo, J.L.; García-Párraga, D.; Esperón, F.; Sánchez-Vizcaíno, J.M. Simultaneous diagnosis of Cetacean morbillivirus infection in dolphins stranded in the Spanish Mediterranean sea in 2011 using a novel Universal Probe Library (UPL) RT-PCR assay. Vet. Microbiol. 2013, 165, 109-114.

82. Rubio-Guerri, C.; Melero, M.; Esperón, F.; Bellière, E.N.; Arbelo, M.; Crespo, J.L.; Sierra, E.; García-Párraga, D.; Sánchez-Vizcaíno, J.M. Unusual striped dolphin mass mortality episode related to cetacean morbillivirus in the Spanish Mediterranean sea. BMC Vet. Res. 2013, 9, e106.

83. Ludlow, M.; McQuaid, S.; Milner, D.; de Swart, R.L.; Duprex, W.P. Pathological consequences of systemic measles virus infection. J. Pathol. 2015, 235, 253-265. 
84. De Swart, R.L.; Ludlow, M.; de Witte, L.; Yanagi, Y.; van Amerongen, G.; McQuaid, S.; Yuksel, S.; Geijtenbeek, T.B.; Duprex, W.P.; Osterhaus, A.D. Predominant infection of CD150+ lymphocytes and dendritic cells during measles virus infection of macaques. PLoS Pathog. 2007, 3, e178.

85. Appel, M.P.G. Pathogenesis of canine distemper. Am. J. Vet. Res. 1969, 30, 1167-1182.

86. Lemon, K.; de Vries, R.D.; Mesman, A.W.; McQuaid, S.; van Amerongen, G.; Yuksel, S.; Ludlow, M.; Rennick, L.J.; Kuiken, T.; Rima, B.K.; et al. Early target cells of measles virus after aerosol infection of non-human primates. PLoS Pathog. 2011, 7, e1001263.

87. Schulman, F.Y.; Lipscomb, T.P.; Moffett, D.; Krafft, A.E.; Lichy, J.H.; Tsai, M.M.; Taubenberger, J.K.; Kennedy, S. Histologic, immunohistochemical, and polymerase chain reaction studies of bottlenose dolphins from the 1987-1988 United States Atlantic coast epizootic. Vet. Pathol. 1997, 34, 288-295.

88. Fernández, A.; Esperón, F.; Herraéz, P.; Espinosa de los Monteros, A.; Clavel, C.; Bernabé, A.; Sanchez-Vizcaino, M.; Verborgh, P.; DeStephanis, R.; Toledano, F.; et al. Morbillivirus and pilot whale deaths, Mediterranean Sea. Emerg. Infect. Dis. 2008, 14, 792-794.

89. Mazzariol, S.; Marcer, F.; Mignone, W.; Serracca, L.; Goria, M.; Marsili, L.; di Guardo, G.; Casalone, C. Dolphin Morbillivirus and Toxoplasma gondii coinfection in a Mediterranean fin whale (Balaenoptera physalus). BMC Vet. Res. 2012, 8, e20.

90. Stone, B.M.; Blyde, D.J.; Saliki, J.T.; Morton, J.M. Morbillivirus infection in live stranded, injured, trapped, and captive cetaceans in southeastern Queensland and northern New South Wales, Australia. J. Wildl. Dis. 2012, 48, 47-55.

91. Soto, S.; Gonzalez, B.; Willoughby, K.; Maley, M.; Olivera, A.; Kennedy, S.; Marco, A.; Domingo, M. Systemic herpesvirus and morbillivirus co-infection in a striped dolphin (Stenella coeruleoalba). J. Comp. Pathol. 2012, 146, 269-273.

92. Taubenberger, J.K.; Tsai, M.; Krafft, A.E.; Lichy, J.H.; Reid, A.H.; Schulman, F.Y.; Lipscomb, T.P. Two morbilliviruses implicated in bottlenose dolphin epizootics. Emerg. Infect. Dis. 1996, 2, 213-216.

93. Lin, W.H.; Kouyos, R.D.; Adams, R.J.; Grenfell, B.T.; Griffin, D.E. Prolonged persistence of measles virus RNA is characteristic of primary infection dynamics. Proc. Natl. Acad. Sci. USA 2012, 109, 14989-14994.

94. Domingo, M.; Vilafranca, M.; Visa, J.; Prats, N.; Trudgett, A.; Visser, I. Evidence for chronic morbillivirus infection in the Mediterranean striped dolphin (Stenella coeruleoalba). Vet. Microbiol. 1995, 44, 229-239.

95. Garg, R.K. Subacute sclerosing panencephalitis. J. Neurol. 2008, 255, 1861-1871.

96. Gutierrez, J.; Issacson, R.S.; Koppel, B.S. Subacute sclerosing panencephalitis: An update. Dev. Med. Child Neurol. 2010, 52, 901-917.

97. Headley, S.A.; Amude, A.M.; Alfieri, A.F.; Bracarense, A.P.; Alfieri, A.A.; Summers, B.A. Molecular detection of Canine distemper virus and the immunohistochemical characterization of the neurologic lesions in naturally occurring old dog encephalitis. J. Vet. Diagn. Invest. 2009, 21, $588-597$.

98. Vandevelde, M.; Kristensen, B.; Braund, K.G.; Greene, C.E.; Swango, L.J.; Hoerlein, B.F. Chronic canine distemper virus encephalitis in mature dogs. Vet. Pathol. 1980, 17, 17-28. 
99. Griffin, D.E.; Lin, W.H.; Pan, C.H. Measles virus, immune control, and persistence. FEMS Microbiol. Rev. 2012, 36, 649-662.

100. Vandevelde, M.; Zurbriggen, A. The neurobiology of canine distemper virus infection. Vet. Microb. 1995, 44, 271-280.

101. Axthelm, M.K.; Krakowka, S. Experimental old dog encephalitis (ODE) in a gnotobiotic dog. Vet. Pathol. 1998, 35, 527-534

102. Maxie, M.G.; Youssef, S. Nervous system. In Jubb, Kennedy, and Palmer's Pathology of Domestic Animals; Maxie, M.G., Ed.; Saunders/Elsevier: Philadelphia, PA, USA, 2007; Volume 1, pp. 405-408.

103. Di Guardo, G. Morbillivirus-host interaction: Lessons from aquatic mammals. Front. Microbiol. 2012, 3, e431.

104. Gomez de Segura, A.; Crespo, E.A.; Pedraza, S.N.; Hammond, P.S.; Raga, J.A. Abundance of small cetaceans in the waters of the central Spanish Mediterranean. Mar. Biol. 2006, 150, 149-160.

105. Schönberger, K.; Ludwig, M.S.; Wildner, M.; Weissbrich, B. Epidemiology of subacute sclerosing panencephalitis (SSPE) in Germany from 2003 to 2009: A risk estimation. PLoS One 2013, 8, e68909.

106. Uchida, K.; Muranaka, M.; Horii, Y.; Murakami, N.; Yamaguchi, R.; Tateyama, S. Non-purulent meningoencephalomyelitis of a Pacific striped dolphin (Lagenorhynchus obliquidens). The first evidence of morbillivirus infection in a dolphin at the Pacific Ocean around Japan. J. Vet. Med. Sci. 1999, 61, 159-162.

107. Kennedy, S. Morbillivirus infections in aquatic mammals. J. Comp. Pathol. 1998, 119, 201-225.

108. Ludlow, M.; de Vries, R.D.; Lemon, K.; McQuaid, S.; Millar, E.; van Amerongen, G.; Yüksel, S.; Verburgh, R.J.; Osterhaus, A.D.ME.; de Swart, R.L.; et al. Infection of lymphoid tissues in the macaque upper respiratory tract contributes to the emergence of transmissible measles virus. J. Gen. Virol. 2013, 94, 1933-1944.

109. Appel, M.J.; Shek, W.R.; Summers, B.A. Lymphocyte-mediated immune cytotoxicity in dogs infected with virulent canine distemper virus. Infect. Immun. 1982, 37, 592-600.

110. Griffin, D.E.; Ward, B.J.; Esolen, L.M. Pathogenesis of measles virus infection: An hypothesis for altered immune responses. J. Infect. Dis. 1994, 170 (Suppl 1), S24-S31.

111. Heaney, J.; Barrett, T.; Cosby, S.L. Inhibition of in vitro leukocyte proliferation by morbilliviruses. J. Virol. 2002, 76, 3579-3584.

112. Schlender, J.; Schnorr, J.J.; Spielhoffer, P.; Cathomen, T.; Cattaneo, R.; Billeter, M.A.; ter Meulen, V.; Schneider-Schaulies, S. Interaction of measles virus glycoproteins with the surface of uninfected peripheral blood lymphocytes induces immunosuppression in vitro. Proc. Natl. Acad. Sci. USA 1996, 93, 13194-13199.

113. Black, F. Epidemiology of Paramyxoviridae. In The Paramyxoviruses; Kingsburry, D.W., Ed.; Plenum Press: New York, NY, USA, 1991; pp. 509-536.

114. Van Bressem, M.-F.; van Waerebeek, K.; Raga, J.A. A review of virus infections of cetaceans and the potential impact of morbilliviruses, poxviruses and papillomaviruses on host population dynamics. Dis. Aquat. Organ. 1999, 38, 53-65. 
115. Rijks, J.M.; Osterhaus, A.D.M.E.; Kuiken, T.; Frölich, K. Morbillivirus Infections. In Infectious Diseases of Wild Mammals and Birds in Europe; Gavier-Widén, D., Duff, J.P., Meredith, A., Eds.; Wiley-Blackwell: Oxford, UK, 2012.

116. Van Bressem, M.F.; Raga, J.A. Viruses of Cetaceans. In Studies in Viral Ecology; Hurst, C., Ed.; John Wiley \& Sons: Hoboken, NJ, USA, 2011; pp. 309-332.

117. Birkun, A., Jr.; Kuiken, T.; Krivokhizhin, S.; Haines, D.M.; Osterhaus, A.D.M.E.; van de Bildt, M.W.; Joiris, C.R.; Siebert, U. Epizootic of morbilliviral disease in common dolphins (Delphinus delphis ponticus) from the Black sea. Vet. Rec. 1999, 144, 85-92.

118. Chiba, M.E.; Saito, M.; Suzuki, N.; Honda, Y.; Yaegashi, N. Measles infection in pregnancy. J. Infect. 2003, 47, 40-44.

119. Giusti, D.; Burette, J.; Nguyen, Y.; Lévêque, N.; Graesslin, O.; Andreoletti, L. Virological diagnosis and management of two cases of congenital measles. J. Med. Virol. 2013, 85, 2136-2138.

120. Di Guardo, G.; Cocumelli, C.; Scholl, F.; di Francesco, C.E.; Speranza, R.; Pennelli, M.; Eleni, C. Morbilliviral encephalitis in a striped dolphin Stenella coeruleoalba calf from Italy. Dis. Aquat. Organ. 2011, 95, 247-251.

121. West, K.L.; Levine, G.; Jacob, J.; Jensen, B.; Sanchez, S.; Colegrove, K.; Rotstein, D. Coinfection and vertical transmission of Brucella and Morbillivirus in a neonatal sperm whale (Physeter macrocephalus) in Hawaii, USA. J. Wildl. Dis. 2014, doi: 10.7589/2014-04-092.

122. Almberg, E.S.; Cross, P.C.; Smith, D.W. Persistence of canine distemper virus in the Greater Yellowstone ecosystem's carnivore community. Ecol. Appl. 2010, 7, 2058-2074.

123. Dobson, A.; Holdo, R.M.; Holt, R.D. Rinderpest. In Encyclopedia of Biological Invasions; Simberloff, D., Rejmánek, M., Eds.; University of California Press: Berkeley, CA, USA, 1991; pp. 597-604.

124. Griffin, D.E.; Bellini, W.J. Measles virus. In Fields Virology, 3rd ed.; Fields, B.N., Knipe, D.M., Howley, P.M., Chanock, R.M., Melnick, J.I., Monath, T.P., Roizman, B., Straus, S.E., Eds.; Lippincott-Raven Publishers: Philadelphia, PA, USA, 1996; pp. 1267-1312.

125. Wohlsein, P.; Puff, C.; Kreutzer, M.; Siebert, U.; Baumgärtner, W. Distemper in a dolphin. Emerg. Infect. Dis. 2007, 13, 1959-1961.

126. Jauniaux, T.; Charlier, G.; Desmecht, M.; Haelters, J.; Jacques, T.; Losson, B.; van Gompel, J.; Tavernier, J.; Coignoul, F. Pathological findings in two fin whales (Balaenoptera physalus) with evidence of morbillivirus infection. J. Comp. Pathol. 2000, 123,198-201.

127. Aguilar, A.; Raga, J.A. The striped dolphin epizootic in the Mediterranean Sea. Ambio 1993, 22, 524-528.

128. Tsur, L.; Goffman, O.; Yakobsen, B.; Moffet, D.; Kennedy, S. Morbillivirus infection in a bottlenose dolphin (Tursiops truncatus) from the Mediterranean Sea. Eur. J. Vet. Pathol. 1997, 2, 83-85.

129. Hersh, S.L.; Odell, D.K.; Asper, E.D. Bottlenose dolphin mortality patterns in the Indian/Banana river system in Florida. In The Bottlenose Dolphin; Leatherwood, S.P., Reeves, R.R., Eds.; Academic Press: San Diego, CA, USA, 1990; pp. 155-164.

130. Update on the dolphin morbillivirus outbreak and the 2013-2014 U.S.Mid-Atlantic bottlenose dolphin (Tursiops truncatus) unusual mortality event. Available online: https://events.iwc.int/ index.php/scientific/SC65B/paper/viewFile/759/757/SC-65b-E03.pdf (accessed on 15 August 2014). 
131. Tomo, I.; Bastianello, S.; Woolford, L.; Kemper, C.; Dickson, C. Kelly, D.; Wang, J.; Bingham, J. Pathology of dolphins during an unusual mortality event in South Australia, 2013. In Proceedings of the 20 Biennial Conference on the Biology of Marine Mammals, Dunedin, New Zealand, 9-13 December 2013.

132. Kennedy, S.; Kuiken, T.; Ross, H.M.; McAliskey, M.; Moffett, D.; McNiven, M.; Carole, M. Morbillivirus infection in two common porpoises (Phocoena phocoena) from the coasts of England and Scotland. Vet. Rec. 1992, 31, 286-290.

133. Jepson, P.D.; Baker, J.R.; Kuiken, T.; Simpson, V.R.; Kennedy, S.; Bennett, P.M. Pulmonary pathology of harbour porpoises (Phocoena phocoena) stranded in England and Wales between 1990 and 1996. Vet. Rec. 2000, 46, 721-728.

134. Siebert, U.; Wünschmann, A.; Weiss, R.; Frank, H.; Benke, H.; Frese, K. Post-mortem findings in harbour porpoises (Phocoena phocoena) from the German North and Baltic Seas. J. Comp. Pathol. 2001, 124, 102-114.

135. Jauniaux, T.; Petitjean, D.; Brenez, C.; Borrens, M.; Brosens, L.; Haelters, J.; Tavernier, T.; Coignoul, F. Post-mortem findings and causes of death of harbour porpoises (Phocoena phocoena) stranded from 1990 to 2000 along the coastlines of Belgium and Northern France. J. Comp. Pathol. 2002, 126, 243-253.

136. Hammond, P.S.; Berggren, P.; Benke, H.; Borchers, D.L.; Collet, A.; Heide-Jorgensen, M.P.; Heimlich, S.; Hiby, A.R.; Leopold, M.F.; Øien, N. Abundance of harbour porpoise and other cetaceans in the North Sea and adjacent waters. J. Appl. Ecol. 2002, 39, 361-376.

137. Forcada, J.; Aguilar, A.; Hammond, P.S.; Pastor, X.; Aguilar, R. Distribution and numbers of striped dolphins in the western Mediterranean sea after the 1990 epizootic outbreak. Mar. Mamm. Sci. 1994, 10, 137-150.

138. Garibaldi, F.; Mignone, W.; Caroggio, P.; Ballardini, M.; Podestà, M.; Bozzetta, E.; Casalone, C.; Marsilio, F.; di Francesco, C.E.; Proietto, U.; et al. Serological evidence of Morbillivirus infection in striped dolphins (Stenella coeruleoalba) found stranded on the Ligurian Sea coast of Italy. In Proceedings of the 22th European Cetacean Society Conference, Egmond aan Zee, The Netherlands, 10-12 March 2008; pp. 192-193.

139. Wierucka, K.; Verborgh, P.; Meade, R.; Colmant, L.; Gauffier, P.; Esteban, R.; de Stephanis, R.; Cañadas, A. Effects of a morbillivirus epizootic on long-finned pilot whales Globicephala melas in Spanish Mediterranean waters. Mar. Ecol. Prog. Ser. 2014, 502, 1-10.

140. Gomez De Segura, A.; Hammond, P.S.; Cañadas, A.; Raga, J.A. Comparing cetacean abundance estimates derived from spatial models and design-based line transect methods. Mar. Ecol. Prog. Ser 2007, 329, 289-299.

141. Soto, S. Morbillivirus Infection in Mediterranean Striped Dolphins (Stenella coeruleoalba) during the 2007 Epidemic and the Post-Epidemic Years. Ph.D. Thesis, Universidad Autonoma de Barcelona, Barcelona, Spain, September 2014.

142. Aguilar, A.; Borrell, A. Abnormally high polychlorinated biphenyl levels in striped dolphins (Stenella coeruleoalba) affected by the 1990-1992 Mediterranean epizootic. Sci. Total Environ. 1994, 154, 237-247. 
143. Aznar, F.J.; Perdiguero, D.; Pérez del Olmo, A.; Repullés, A.; Agustí, C.; Raga, J.A. Changes in epizoic crustacean infestations during cetacean die-offs: The mass mortality of Mediterranean striped dolphins Stenella coeruleoalba revisited. Dis. Aquat. Org. 2005, 67, 239-247

144. Fossi, M.C.; Casini, S.; Marsili, L. Potential toxicological hazard due to endocrine-disrupting chemicals on Mediterranean top predators: State of art, gender differences and methodological tools. Environ. Res. 2007, 104, 174-182.

145. Valsecchi, E.; Amos, W.; Raga, J.A.; Podestà, M.; Sherwin, W. The effects of inbreeding on mortality during a morbillivirus outbreak in the Mediterranean striped dolphin (Stenella coeruleoalba). Anim. Cons. 2004, 7, 139-146.

146. Casalone, C.; Mazzariol, S.; Pautasso, A.; di Guardo, G.; di Nocera, F.; Lucifora, G.; Ligios, C.; Franco, A.; Fichi, G.; Cocumelli, C.; et al. Cetacean strandings in Italy: An unusual mortality event along the Tyrrhenian Sea coast in 2013. Dis. Aquat. Org. 2014, 109, 81-86.

147. Nortobartolo di Sciara, G.; Birkun, G. Conserving Whales, Porpoises and Dolphins in the Mediterranean and Black Seas: An ACCOBAMS Status Report; ACOBAMS: Monaco, Principality of Monaco, 2010; p. 212.

148. McLellan, W.; Friedlaender, A.; Mead, J.; Potter, C.; Pabst, D.A. Analysing 25 years of bottlenose dolphin (Tursiops truncatus) strandings along the Atlantic coast of the USA: Do historic records support the coastal migratory stock hypothesis. J. Cet. Res. Manag. 2002, 4, 297-304.

149. Rosel, P.E.; Hansen, L.; Hohn, A.A. Restricted dispersal in a continuously distributed marine species: Common bottlenose dolphins Tursiops truncatus in coastal waters of the western North Atlantic. Mol. Ecol. 2009, 18, 5030-5045.

150. Lipscomb, T.P.; Kennedy, S.; Moffett, D.; Krafft, A.; Klaunberg, B.A.; Lichy, J.H.; Regan G.T.; Worthy, G.A.; Taubenberger, J.K. Morbilliviral epizootic in bottlenose dolphins of the Gulf of Mexico. J. Vet. Diagn. Invest. 1996, 8, 283-290.

151. Worthy, A.J. Patterns of Bottlenose Dolphin, Tursiops truncatus, Strandings in Texas. In Characteristics and Causes of Texas Marine Strandings; Zimmennan, R., Ed.; NOAA Technical Report NMFS 143; U.S. Department Commerce: Galveston, TX, USA, 1998; p. 85.

152. Cantor, M.; Wedekin, L.L.; Daura-Jorge, F.G.; Rossi-Santos, M.R.; Simoes-Lopes, P. Assessing population parameters and trends of Guiana dolphins (Sotalia guianensis): An eight-year mark-recapture study. Mar. Mamm. Sci. 2012, 28, 63-83.

153. Rossi-Santos, M.; Wedekin, L.L.; Sousa-Lima, R.S. Distribution and habitat use of small cetaceans off Abrolhos Bank, eastern Brazil. LAJAM 2006, 5, 23-28.

154. Martins, C.C.A.; Morete, M.E.; Engel, M.H.; Freitas, A.C., Secchi, E.R.; Kinas, P.G. Aspects of habitat use patterns of humpback whales in the Abrolhos Bank, Brazil, breeding ground. Mem. Qld. Mus. 2001, 47, 563-570.

155. Wedekin, L.L.; Freitas, A.; Engel, M.H.; Sazima, I. Rough-toothed dolphins (Steno bredanensis) catch diskfishes while interacting with humpback whales (Megaptera novaeangliae) off Abrolhos Bank breeding ground, southwest Atlantic. Aquat. Mamm. 2004, 30, 327-329.

156. Groch, K.R.; Carvalho, V.L.; Meirelles, A.C.O.; Gonzales-Viera, O.; Kolesnikovas, C.K.M.; Groch, K.R.; Zucca, D.; Fernández, A.; Catão-Dias, J.L. Morbillivirus in live stranded cetaceans from Brazilian coast: Immunohistochemical evidence. In Proceedings of the 20th Biennial Conference on the Biology of Marine Mammals, Dunedin, New Zealand, 9-13 December 2013; pp. 85-86. 
157. Bodewes, R.; Morick, D.; van de Bildt, M.W.G.; Osinga, N.; Rubio Garcia, A.; Sanchez Contreras, G.J.; Smits, S.L.; Reperant, L.A.P.; Kuiken, T.; Osterhaus, A.D.M.E. 2014 Prevalence of phocine distemper virus specific antibodies: Bracing for the next seal epizootic in north-western Europe. Emerg. Microbes. Infect. 2013, 2, e3.

158. Prachayangprecha, S.; Schapendonk, C.M.; Koopmans, M.P.; Osterhaus, A.D.M.E.; Schürch, A.C.; Pas, S.D.; van der Eijk, A.A.; Poovorawan, Y.; Haagmans, B.L.; Smits, S.L. Exploring the potential of next-generation sequencing in detection of respiratory viruses. J. Clin. Microbiol. 2014, 52, 3722-3730.

159. Muniraju, M.; Munir, M.; Parthiban, A.R.; Banyard, A.C.; Bao, J.; Wang, Z.; Ayebazibwe, C.; Ayelet, G.; El Harrak, M.; Mahapatra, M.; et al. Molecular evolution of peste des petits ruminants virus. Emerg. Infect. Dis. 2014, 20, 2023-2033.

160. Drexler, J.F.; Corman, V.M.; Müller, M.A.; Maganga, G.D.; Vallo, P.; Binger, T.; Gloza-Rausch, F.; Cottontail, V.M.; Rasche, A.; Yordanov, S.; et al. Bats host major mammalian paramyxoviruses. Nat. Commun. 2012, 3, e796.

161. Mazzariol, S.; Peletto, S.; Mondin, A.; Centelleghe, C.; di Guardo, G.; di Francesco, C.E.; Casalone, C.; Acutis, P.L. Dolphin morbillivirus infection in a captive harbor seal (Phoca vitulina). J. Clin. Microbiol. 2013, 51, 708-711.

162. Van de Bildt, M.W.; Martina, B.E.; Sidi, B.A.; Osterhaus, A.D.M.E. Morbillivirus infection in a bottlenose dolphin and a Mediterranean monk seal from the Atlantic coast of West Africa. Vet. Rec. 2001, 148, 210-211.

163. Grenfell, B.T.; Lonergan, M.E.; Harwood, J. Quantitative investigations of the epidemiology of phocine distemper virus (PDV) in European common seal populations. Sci. Total Environ. 1992, $115,15-29$.

(C) 2014 by the authors; licensee MDPI, Basel, Switzerland. This article is an open access article distributed under the terms and conditions of the Creative Commons Attribution license (http://creativecommons.org/licenses/by/4.0/). 